\title{
Probability Based Corrosion Control for High Level Waste Tanks: Interim Report
}

\author{
E. N. Hoffman \\ K.H. Subramanian \\ Savannah River National Laboratory \\ Materials Science and Technology Directorate
}

Publication Date: February 2008

\section{Washington Savannah River Company Savannah River Site Aiken SC 29808}

This document was prepared in connection with work done under Contract No. DE-AC09-96SR18500 with the U. S. Department of Energy 
WSRC-STI-2007-00712

\section{DISCLAIMER}

This report was prepared as an account of work sponsored by an agency of the United States Government. Neither the United States Government nor any agency thereof, nor any of their employees, makes any warranty, express or implied, or assumes any legal liability or responsibility for the accuracy, completeness, or usefulness of any information, apparatus, product, or process disclosed, or represents that its use would not infringe privately owned rights. Reference herein to any specific commercial product, process, or service by trade name, trademark, manufacturer, or otherwise does not necessarily constitute or imply its endorsement, recommendation, or favoring by the United States Government or any agency thereof. The views and opinions of authors expressed herein do not necessarily state or reflect those of the United States Government or any agency thereof. 


\section{Signatures on File}


Table of Contents

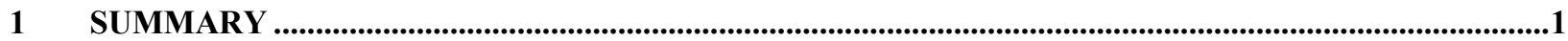

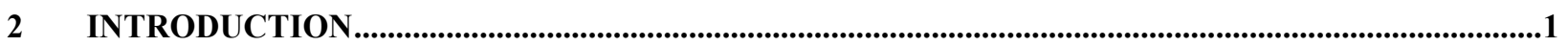

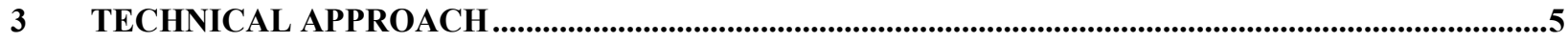

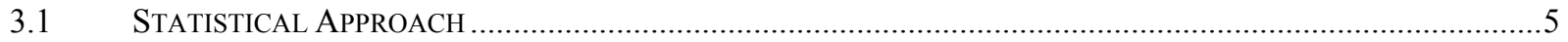

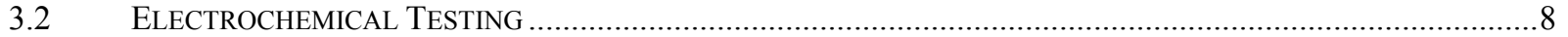

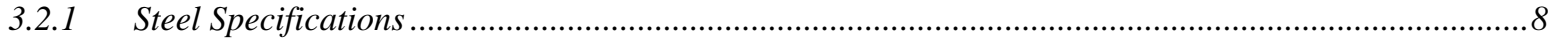

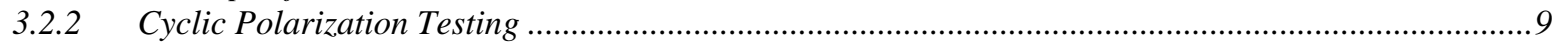

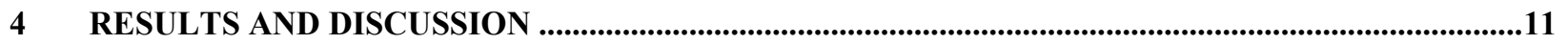

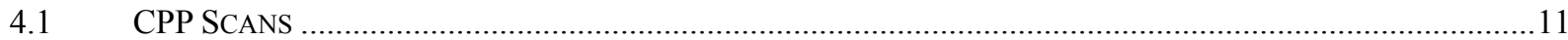

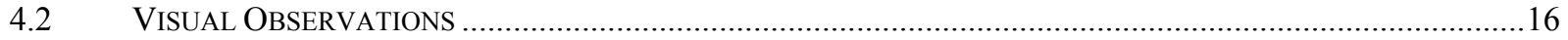

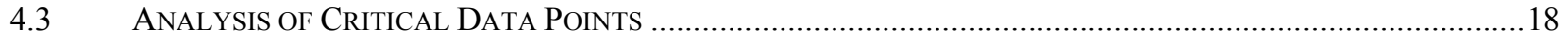

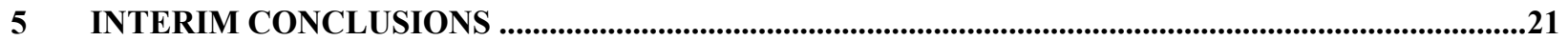




\section{LIST OF TABLES}

TABLE 1: CORROSION CONTROL LIMITS FOR THE HLW TANKS: MINIMUM CORROSION-INHIBITED CONCENTRATION LIMITS

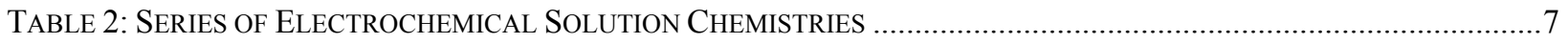

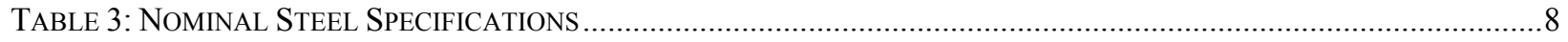

TABle 4: Ion Chromatography Results Prior to ElectrochemicAl SCAN USING C077 SOLUTION..................10

TABLE 5: TEST DATA WHICH INDICATED SignifiCANT CORROSION UPON ViSUAL OBSERVATION ............................19

\section{List of Figures}

Figure 1: CORRosion CONTROL Limits AS A FunCtion OF Nitrate CONCENTRATION ..........................................

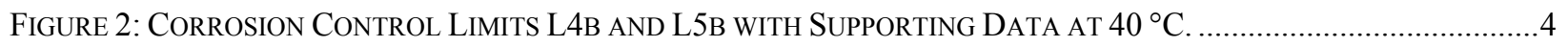

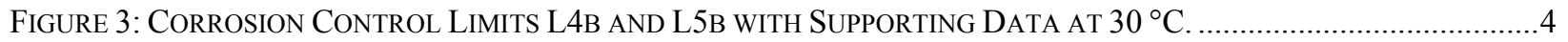

Figure 4: Chemistry Control EnVElope With ProbabiLity of PitTing ..........................................................5

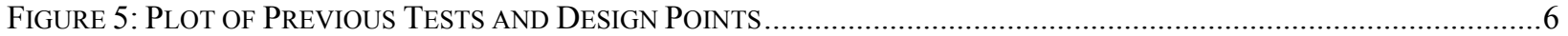

Figure 6: MicrostruCtURE/SEM MicrograPH OF ASTM A537 CL.1 STEEL. ...................................................9

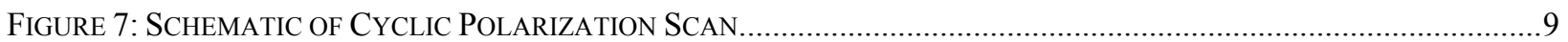

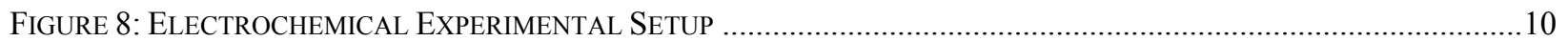

Figure 9: Open-Circuit Potential as a FunCtion of Nitrate ConcEnTRATiOn ............................................12

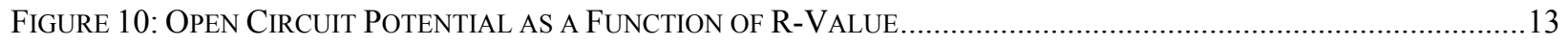

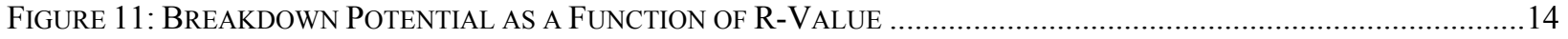

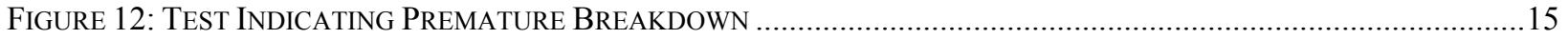

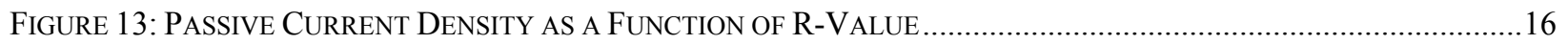

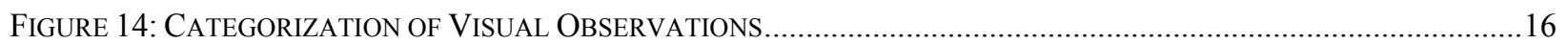

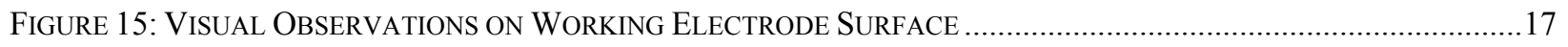

Figure 16: CORROSION CHANGES DURING ELECTROCHEMICAL RUN USING C061 .................................................18

Figure 17: CRitical Locations of Greatest Potential CHEMistry CONTROL Reductions ..........................19

FIGURE 18: CPP SCANS WITH LOWEST LEVEL OF NITRITE INHIBITOR ADDITION...............................................20

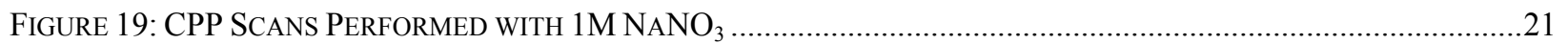




\section{SUMMARY}

Controls on the solution chemistry (minimum nitrite and hydroxide concentrations) are in place to prevent the initiation and propagation of pitting and stress corrosion cracking in high level waste (HLW) tanks. These controls are based upon a series of experiments performed on carbon steel coupons in simulated waste solutions. An experimental program was undertaken to investigate reducing the minimum molar nitrite concentration required to confidently inhibit pitting. A statistical basis to quantify the probability of pitting for the tank wall, when exposed to various dilute solutions, is being developed. Electrochemical and coupon testing are being performed within the framework of the statistical test matrix to determine the minimum necessary inhibitor concentrations and develop a quantitative model to predict pitting propensity.

A subset of the original statistical test matrix was used to develop an applied understanding of the corrosion response of the carbon steel in the various environments. The interim results suggest that there exists some critical nitrite concentration that sufficiently inhibits against localized corrosion mechanisms due to nitrates/chlorides/sulfates, beyond which further nitrite additions are unnecessary. The combination of visual observation and the cyclic potentiodynamic polarization scans indicate the potential for significant inhibitor reductions without consequence specifically at nitrate concentrations near $1 \mathrm{M}$. The complete data sets will be used to determine the statistical basis to confidently inhibit against pitting using nitrite inhibition with the current $\mathrm{pH}$ controls. Once complete, a revised chemistry control program will be devised based upon the probability of pitting specifically for dilute solutions which will allow for tank specific chemistry control implementation.

\section{INTRODUCTION}

Large underground carbon steel tanks are used to store high level radioactive waste at the DOE Savannah River Site (SRS). An assessment of the potential degradation mechanisms of the high level waste (HLW) tanks determined that nitrate-induced pitting corrosion and stress corrosion cracking were the two most significant degradation mechanisms.[1] Controls on the solution chemistry (minimum nitrite and hydroxide concentrations) are in place to prevent the initiation and propagation of pitting and stress corrosion cracking in the tanks. These controls are based upon a series of experiments performed using simulated solutions on materials used for construction of the tanks. The addition of hydroxide and nitrite keep the $\mathrm{pH}$ above the vulnerable regime and inhibits the cathodic reaction.

The current inhibitor concentration limits are organized and listed in Table 1 by nitrate concentration range, and shown graphically in Figure 1as a function of the nitrate concentration. The hydroxide and nitrite concentration limits address nitrate-induced corrosion in the concentration range $0.02 \mathrm{M}$ to $8.5 \mathrm{M}$ nitrate in five limits, labeled L1 to L5. Limits L1, L2, and L3 cover the range $1 \mathrm{M}$ to $8.5 \mathrm{M}$ and specify the minimum hydroxide concentration and the minimum sum of the hydroxide and nitrite concentrations that are required to prevent stress corrosion cracking. Limits L4 and L5 control nitrate concentrations below $1 \mathrm{M}$.

Table 1: Corrosion Control Limits for the HLW Tanks: Minimum Corrosion-Inhibited Concentration Limits

\begin{tabular}{|c|c|c|c|}
\hline Applicability & Parameter & Minimum Needed & Units \\
\hline \multirow{2}{*}{ L1. 5.5 $<\left[\mathbf{N O}_{3}{ }^{-}\right] \leq \mathbf{8 . 5}$ Molar } & {$\left[\mathrm{OH}^{-}\right]$} & 0.6 & Molar \\
\cline { 2 - 5 } & {$\left[\mathrm{OH}^{-}\right]+\left[\mathrm{NO}_{2}^{-}\right]$} & 1.1 & Molar \\
\hline \multirow{2}{*}{ L2. 2.75 $<\left[\mathrm{NO}_{3}^{-}\right] \leq \mathbf{5 . 5}$ Molar } & {$[\mathrm{OH}-]$} & 0.3 & Molar \\
\cline { 2 - 5 } & {$\left[\mathrm{OH}^{-}\right]+\left[\mathrm{NO}_{2}^{-}\right]$} & 1.1 & Molar \\
\hline \multirow{2}{*}{ L3.1.0 $\leq\left[\mathrm{NO}_{3}^{-}\right] \leq \mathbf{2 . 7 5}$ Molar } & {$\left[\mathrm{OH}^{-}\right]$} & $0.1\left[\mathrm{NO}_{3}^{-}\right]$ & Molar \\
\cline { 2 - 5 } & {$\left[\mathrm{OH}^{-}\right]+\left[\mathrm{NO}_{2}^{-}\right]$} & $0.4\left[\mathrm{NO}_{3}^{-}\right]$ & Molar \\
\hline \multirow{2}{*}{ L4. 0.02 $<\left[\mathrm{NO}_{3}^{-}\right]<\mathbf{1 . 0}$ Molar AND $\left[\mathrm{OH}^{-}\right]<\mathbf{1 . 0} \mathrm{Molar}^{-}$} & \multicolumn{2}{|c}{} \\
\hline \multirow{2}{*}{ L4a. - Either Inhibit with $[\mathrm{OH}-]$ OR } & {$\left[\mathrm{OH}^{-}\right]$} & 1.0 & Molar \\
\hline
\end{tabular}




\begin{tabular}{|c|c|c|c|}
\hline Applicability & Parameter & Minimum Needed & Units \\
\hline \multicolumn{4}{|l|}{ Inhibit with $\left[\mathrm{NO}_{2}^{-}\right]$} \\
\hline L4b. For $\left[\mathrm{NO}_{3}^{-}\right]$ & {$\left[\mathrm{NO}_{2}^{-}\right]$} & $0.038 \times\left[\mathrm{NO}_{3}^{-}\right] \times 10^{1.64}$ & Molar \\
\hline L4c. For [Cl-] & {$\left[\mathrm{NO}_{2}^{-}\right]$} & $6.11 \times 10^{[1.64+1.34 \times \log [\mathrm{Cl}-]]}$ & Molar \\
\hline \multirow[t]{2}{*}{ L4d. For $\left[\mathrm{SO}_{4}^{-}\right]$} & {$\left[\mathrm{NO}_{2}^{-}\right]$} & $0.04 \times 10^{[1.64+0.84 \log [\mathrm{SO} 42-]]}$ & Molar \\
\hline & $\mathrm{pH}$ & 10.3 & $\begin{array}{l}\mathrm{pH} \\
\text { Units }\end{array}$ \\
\hline \multicolumn{4}{|c|}{ L5. $\left[\mathrm{NO}_{3}{ }^{-}\right] \leq 0.02$ Molar AND $[\mathrm{OH}-]<1.0$ Molar } \\
\hline $\begin{array}{l}\text { L5a. - Either Inhibit with [OH-] OR } \\
\text { Inhibit with }\left[\mathrm{NO}_{2}^{-}\right]\end{array}$ & {$\left[\mathrm{OH}^{-}\right]$} & 1.0 & Molar \\
\hline L5b. For $\left[\mathrm{NO}_{3}^{-}\right]$ & {$\left[\mathrm{NO}_{2}^{-}\right]$} & $0.038 \times\left[\mathrm{NO}_{3}^{-}\right] \times 10^{1.64}$ & Molar \\
\hline L5c. For $\left[\mathrm{Cl}^{-}\right]$ & {$\left[\mathrm{NO}_{2}^{-}\right]$} & $6.11 \times 10^{[1.64+1.34 \times \log [\mathrm{Cl}-]]}$ & Molar \\
\hline \multirow[t]{2}{*}{ L5d. For $\left[\mathrm{SO}_{4}^{-}\right]$} & {$\left[\mathrm{NO}_{2}^{-}\right]$} & $0.04 \times 10^{[1.64+0.84 \log [\mathrm{SO} 4-]]}$ & Molar \\
\hline & $\mathrm{pH}$ & 10.3 & $\begin{array}{l}\mathrm{pH} \\
\text { Units }\end{array}$ \\
\hline $\begin{array}{l}\text { L6. Influents to waste tank from } \\
\text { other areas on site.* }\end{array}$ & $\mathrm{pH}$ & 9.5 & $\begin{array}{l}\mathrm{pH} \\
\text { Units }\end{array}$ \\
\hline
\end{tabular}

Limits L4 and L5 apply to dilute waste solutions, i.e. solutions with a nitrate concentration $<1 \mathrm{M}$, where nitrateinduced pitting, chloride-induced pitting, and sulfate-induced pitting are the corrosion mechanisms of concern. Pitting has not been typically been observed in wastes containing $>1 \mathrm{M}$ nitrate, because these wastes contain high hydroxide concentrations, which typically prevent this form of localized corrosion. Tanks subject to the L4 and L5 limits are those that prepare feed to the vitrification facility and those that receive and store dilute low-heat wastes, e.g. recycle stream from the vitrification facility. Pitting may be prevented by either a minimum hydroxide concentration or by a minimum nitrite concentration along with a minimum $\mathrm{pH}$. Limit L4a specifies the minimum hydroxide concentration of $1 \mathrm{M}$ and is based on the historical experience of the absence of pitting at $\geq 1 \mathrm{M}$ hydroxide concentration. Limit L $4 \mathrm{~b}$ specifies the minimum nitrite concentration required to prevent pitting over the 0.02 to 1 $\mathrm{M}$ nitrate concentration range at $40{ }^{\circ} \mathrm{C}$. 


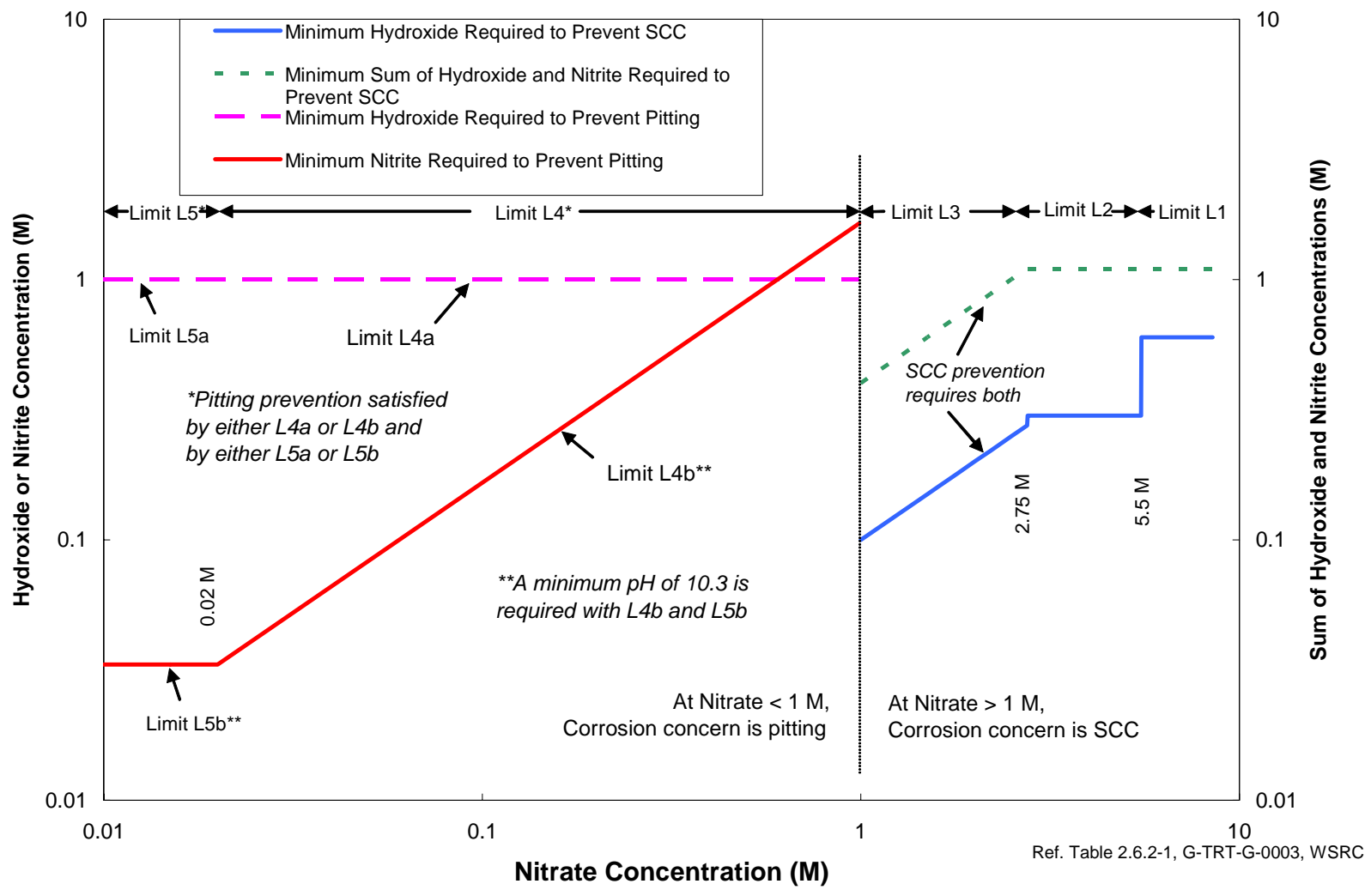

Figure 1: Corrosion Control Limits as a Function of Nitrate Concentration

Limit L4 is based on the results of electrochemical polarization scans and coupon immersion tests.[2,3] A leastsquares fit of the relevant nitrate concentration and test temperature to the minimum nitrite concentration established by the polarization scans at temperatures of $23,30,40,50$, and $60{ }^{\circ} \mathrm{C}$ forms the basis for the limit. Figure 2 and 3 show the data at $40^{\circ} \mathrm{C}$ and $30^{\circ} \mathrm{C}$ with the $\mathrm{L} 4 \mathrm{~b}$ limit. $\mathrm{L} 4 \mathrm{~b}$ incorporates a safety factor of 1.5 on the required nitrite concentration, which was selected based on engineering judgment. Nitrite inhibition is allowed by Limit L4b (and L5b) only up to $40^{\circ} \mathrm{C}$; higher temperatures require the application of L4a (and L5a) up to a maximum temperature of $100^{\circ} \mathrm{C}$. The addition of the L5 limits sets a lower bound on the required nitrite concentration independent of the nitrate concentration. Limits L4 and L5 also contain experimentally determined minimum nitrite limits for chloride and sulfate, which are also known to be able to induce pitting in carbon steel.[4] In the event that the nitrate anion is in low concentration and is not the principal corrosive anion, minimum nitrite levels can be calculated based upon the chloride or sulfate concentrations. The greatest nitrite concentration based on nitrate, chloride, or sulfate becomes the controlling limit. 


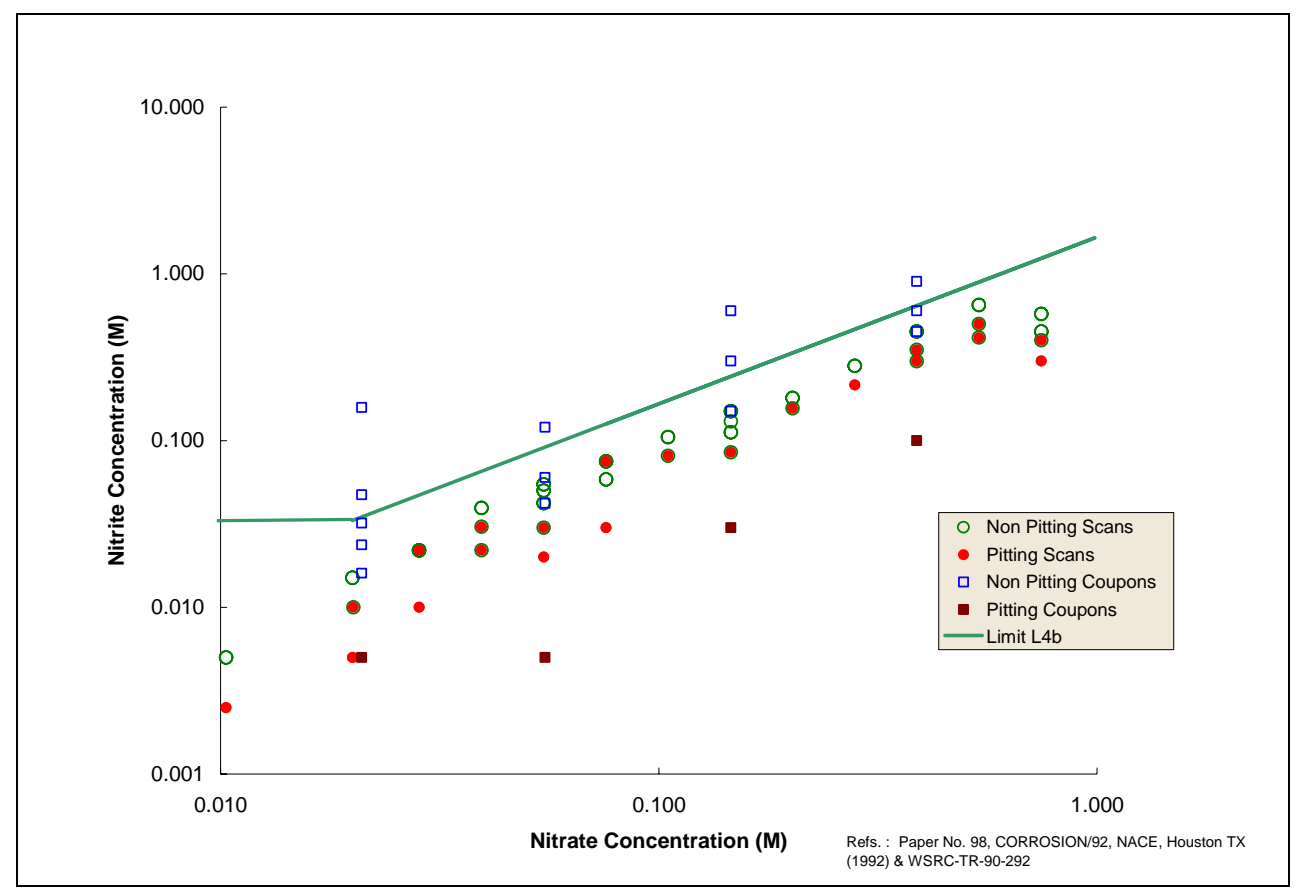

Figure 2: Corrosion Control Limits L4b and L5b with Supporting Data at $40^{\circ} \mathrm{C}$.

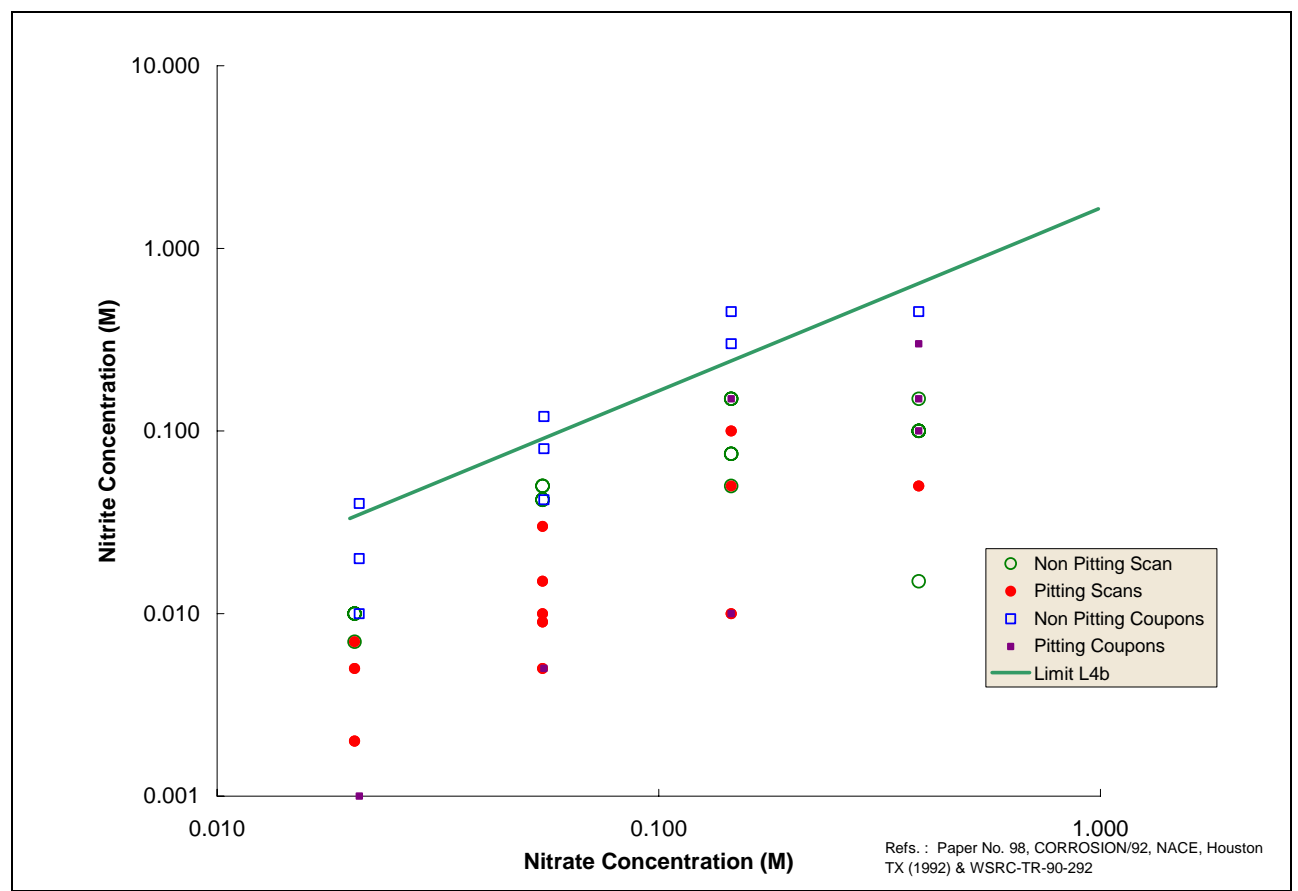

Figure 3: Corrosion Control Limits L4b and L5b with Supporting Data at $30{ }^{\circ} \mathrm{C}$.

The chemistry control program has thus far been implemented by applying a safety factor on the data based upon engineering judgment. The ideal chemistry control program would add the lowest volume of salts to maintain the solution chemistry at a desired concentration to minimize corrosion vulnerabilities. It was proposed that a probability based approach can be used to quantify the risk associated with the chemistry control envelope. This can lead to an application specific chemistry control program, e.g. broadening the envelope for closure goals, while maintaining current levels for long-term storage. 
Two options to relax the chemistry control program without significantly affecting the risk of pitting (where $\left[\mathrm{NO}_{3}{ }^{-}\right]$ < 1M) were considered: (1) Reduce hydroxide limits, or (2) Reduce required nitrite concentration. An experimental program was undertaken to investigate option 2, i.e. the minimum molar nitrite concentration required to confidently inhibit pitting.

\section{TECHNICAL APPROACH}

The technical approach to develop a probability based chemistry control program was based upon gathering sufficient data to develop a predictive tool for corrosion vulnerability. Electrochemical testing and coupon exposure testing will be done with the framework of the statistical test matrix to build the database which will be used for predictive purposes. The electrochemical testing was done to determine the electrochemical regimes in which low carbon steel is susceptible to pitting, while the coupon exposure testing is planned as confirmatory. The electrochemical test approach is presented here, while the coupon exposure tests will be integrated into the results once the test program is complete.

\subsection{Statistical Approach}

A statistical basis to quantify the probability of pitting for the tank wall, when exposed to various dilute solutions, is to be developed. A logistical regression analysis was chosen to develop the probability in terms of the relationship between the nitrate and nitrite concentrations; this type of regression analysis is recommended where the response or test result is binary in form, i.e. either pitting is present or is absent (no pitting). Based on the entire data set of laboratory pitting test results, logistical regression analysis yields curves of constant probability of pitting for various sets of nitrate/nitrite concentrations as shown in Figure 4.[5] As stated above, the current chemistry control program for pitting prevention is based on a least-squares fit of the minimum nitrite concentrations at which pitting was absent to the nitrate concentrations at which the tests were performed. However, because there is scatter in these data (some nitrite/nitrate combinations yield both a pitting and a no-pitting response in duplicate tests, for example), the logistical regression analysis finds a probability of pitting to be near $20 \%(0.20)$ rather than near $0 \%$ for the set of nitrate and nitrite concentrations defined by the corrosion control program's limit $4 \mathrm{~b}$. Figure 4 includes the $10 \%$ and $50 \%$ probability of pitting curves for comparison.

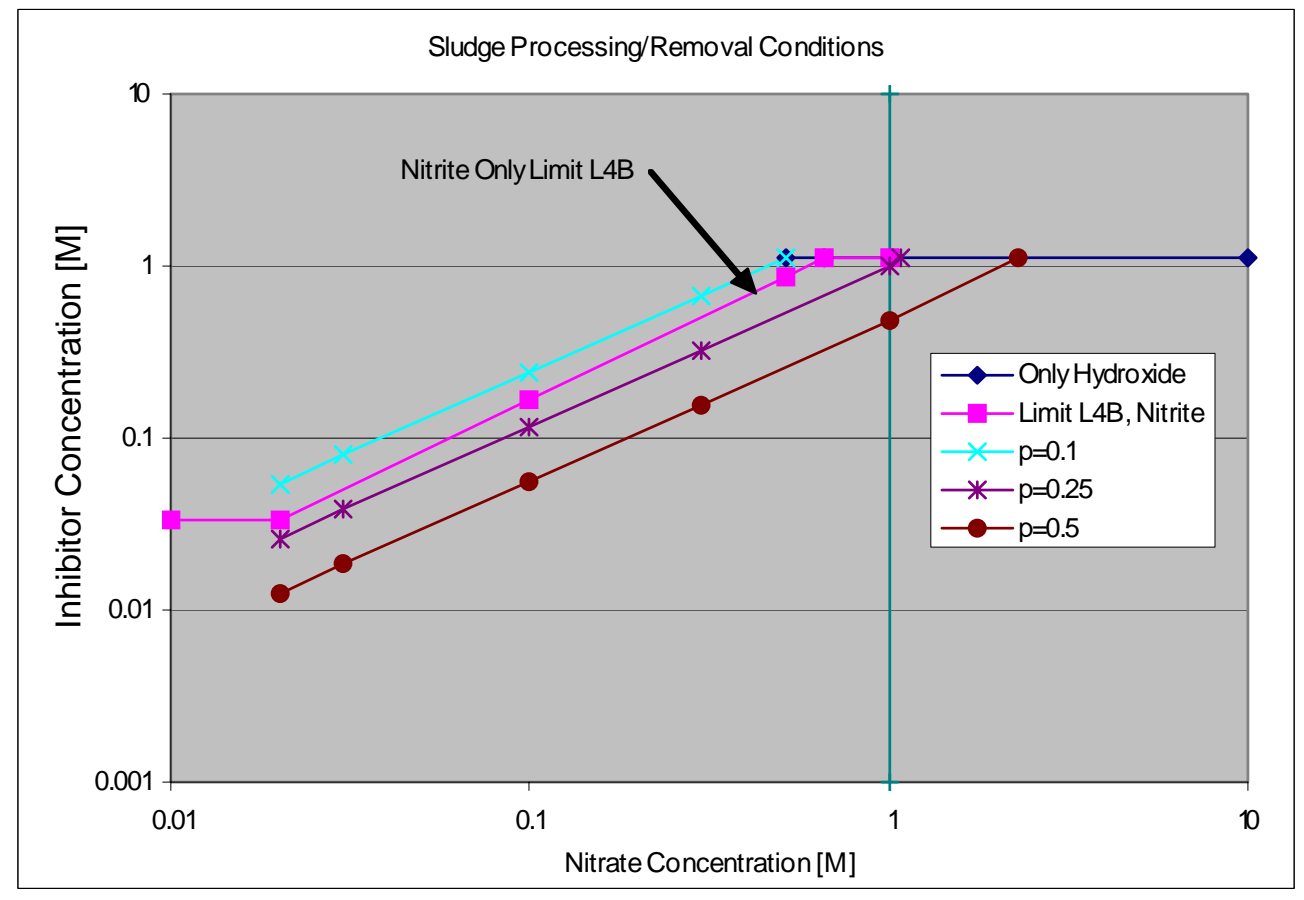

Figure 4: Chemistry Control Envelope with Probability of Pitting 
The logistical regression analysis was used to identify an additional 105 design points to be tested to ensure nopitting predictions with a high level of confidence. Figure 5 provides a plot of the existing data and the design points where a pitted outcomes from various testing programs are represented by a blue " $X$ " or a red " $X$ " and outcomes that showed no pitting are represented by a solid blue circle "•" or a solid green circle "•". The data represented in blue are the results of the short experimental study performed recently in support of this task, while the other data is a compilation of historical data. The pitted outcomes are a larger size in this plot to enhance their identification. Most of the available data were taken with salt solutions of relatively low molar concentrations of nitrate and nitrite. Figure 5 also provides a plot of the new design points ( $\square$ ) along with the previous results. These points should complement the available data and help select and develop an appropriate, representative statistical model for the interpretation of these data. The model may then be used to establish a rule(s) for the use of nitrite to confidently inhibit nitrate induced corrosion pitting.

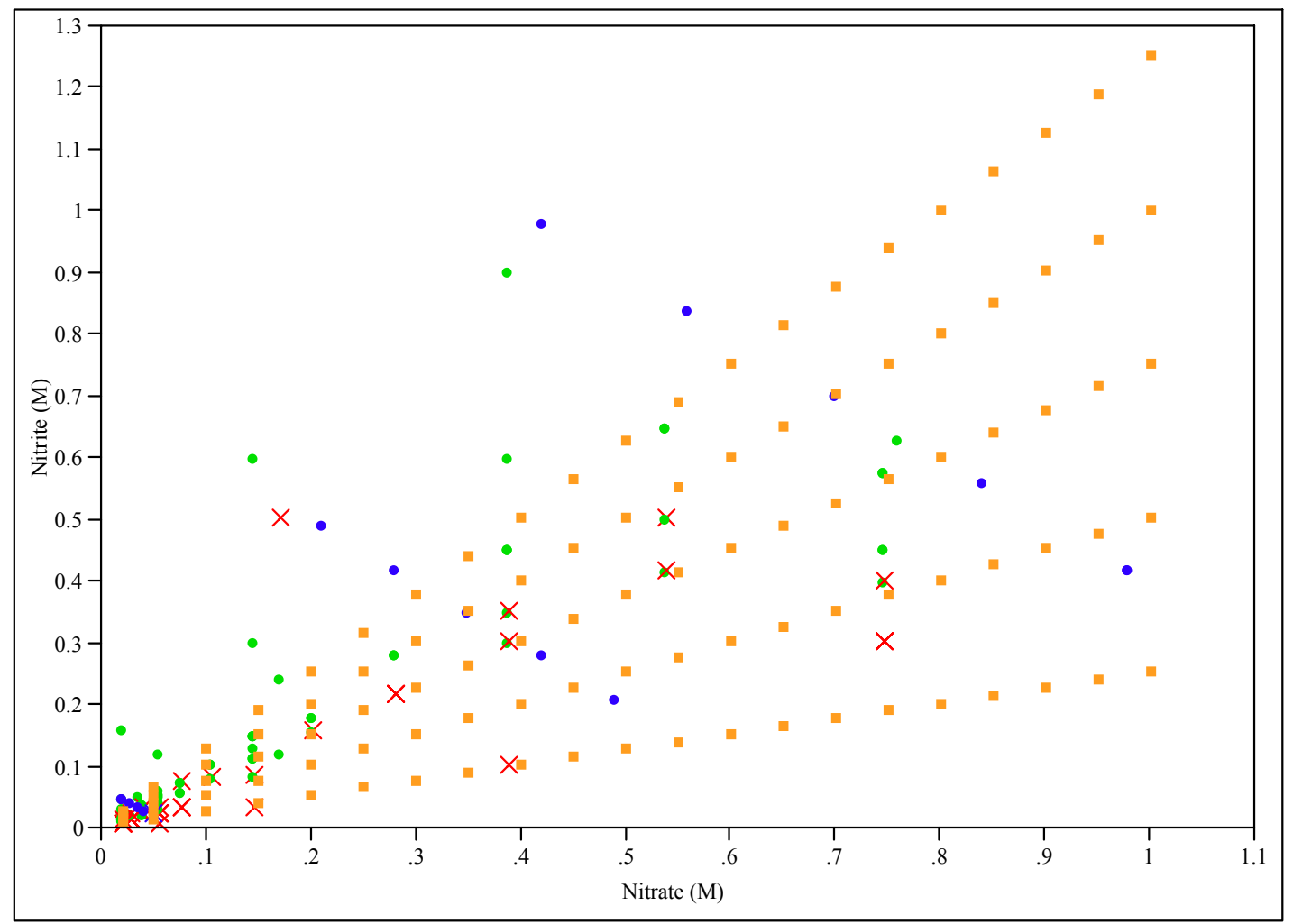

\section{Figure 5: Plot of Previous Tests and Design Points}

By treating the past corrosion pitting study data as a binary function, leading to either a pit or no-pit situation, a statistical model was applied and additional solution chemistries were elected for study. Of 105 total solution chemistries identified for experimentation, 52 design points were evaluated, selecting every other point in order to spread out the solution chemistry design points.

The specific constituents of the solution chemistries that were tested are shown in Table 2. The concentration of the nitrate and the nitrite anions were the design points as determined by the test matrix. However, other aggressive anions, i.e. chloride and sulfate, known to be inhibitor controlling in sufficient quantities, were added to the solutions chemistries to provide a more representative solution.[6] The concentration of chlorides and sulfates in the solutions tested were calculated based upon the maximum allowable per current chemistry control programs as a function of the nitrite inhibitor. For example, solution 105 has a nitrite concentration of $1.25 \mathrm{M}$ corresponding to an allowable of $0.018 \mathrm{M}$ chloride and 0.0672 sulfate per the chemistry control standards. In addition, the chemistry control program has a minimum $\mathrm{pH}$ requirement of 10.3, maintained in the test with the appropriate ratio of carbonate/bicarbonate vs. sodium hydroxide typically credited in the HLW tanks. The $\mathrm{pH}$ was maintained through 
use of a buffered solution rather than sodium hydroxide due to its potential depletion from reaction with carbon dioxide thereby reducing the $\mathrm{pH}$ of the test solution. [7]

Table 2: Series of Electrochemical Solution Chemistries

\begin{tabular}{|c|c|c|c|c|c|c|}
\hline Solution Label & $\mathrm{NO}_{3}^{-}[\mathrm{M}]$ & $\mathrm{NO}_{2}^{-}[\mathrm{M}]$ & $\mathrm{Cl}^{-}[\mathrm{M}]$ & $\mathrm{SO}_{4}{ }^{2-}[\mathrm{M}]$ & $\mathrm{HCO}_{3}^{-}[\mathrm{M}]$ & $\mathrm{CO}_{3}{ }^{2-}[\mathrm{M}]$ \\
\hline $\mathrm{C} 105$ & 1.000 & 1.250 & 0.018 & 0.672 & 0.813 & 0.438 \\
\hline $\mathrm{C} 103$ & 1.000 & 0.750 & 0.012 & 0.366 & 0.488 & 0.263 \\
\hline $\mathrm{C} 101$ & 1.000 & 0.250 & 0.005 & 0.099 & 0.163 & 0.088 \\
\hline C099 & 0.950 & 0.950 & 0.015 & 0.485 & 0.618 & 0.333 \\
\hline $\mathrm{C} 097$ & 0.950 & 0.475 & 0.009 & 0.212 & 0.309 & 0.166 \\
\hline $\mathrm{C} 095$ & 0.900 & 1.125 & 0.017 & 0.593 & 0.731 & 0.394 \\
\hline $\mathrm{C} 093$ & 0.900 & 0.675 & 0.012 & 0.323 & 0.439 & 0.236 \\
\hline C091 & 0.900 & 0.225 & 0.005 & 0.087 & 0.146 & 0.079 \\
\hline C089 & 0.850 & 0.850 & 0.014 & 0.424 & 0.553 & 0.298 \\
\hline $\mathrm{C} 087$ & 0.850 & 0.425 & 0.008 & 0.186 & 0.276 & 0.149 \\
\hline $\mathrm{C} 085$ & 0.800 & 1.000 & 0.015 & 0.515 & 0.650 & 0.350 \\
\hline $\mathrm{C} 083$ & 0.800 & 0.600 & 0.011 & 0.280 & 0.390 & 0.210 \\
\hline $\mathrm{C} 081$ & 0.800 & 0.200 & 0.005 & 0.076 & 0.130 & 0.070 \\
\hline $\mathrm{C} 079$ & 0.750 & 0.750 & 0.012 & 0.366 & 0.488 & 0.263 \\
\hline $\mathrm{C} 077$ & 0.750 & 0.375 & 0.007 & 0.160 & 0.244 & 0.131 \\
\hline $\mathrm{C} 075$ & 0.700 & 0.875 & 0.014 & 0.439 & 0.569 & 0.306 \\
\hline $\mathrm{C} 073$ & 0.700 & 0.525 & 0.010 & 0.239 & 0.341 & 0.184 \\
\hline $\mathrm{C} 071$ & 0.700 & 0.175 & 0.004 & 0.065 & 0.114 & 0.061 \\
\hline $\mathrm{C} 069$ & 0.650 & 0.650 & 0.011 & 0.308 & 0.423 & 0.228 \\
\hline $\mathrm{C} 067$ & 0.650 & 0.325 & 0.007 & 0.135 & 0.211 & 0.114 \\
\hline $\mathrm{C} 065$ & 0.600 & 0.750 & 0.012 & 0.366 & 0.488 & 0.263 \\
\hline $\mathrm{C} 063$ & 0.600 & 0.450 & 0.009 & 0.199 & 0.293 & 0.158 \\
\hline $\mathrm{C} 061$ & 0.600 & 0.150 & 0.004 & 0.054 & 0.098 & 0.053 \\
\hline $\mathrm{C} 059$ & 0.550 & 0.550 & 0.010 & 0.253 & 0.358 & 0.193 \\
\hline $\mathrm{C} 057$ & 0.550 & 0.275 & 0.006 & 0.111 & 0.179 & 0.096 \\
\hline $\mathrm{C} 055$ & 0.500 & 0.625 & 0.011 & 0.294 & 0.406 & 0.219 \\
\hline $\mathrm{C} 053$ & 0.500 & 0.375 & 0.007 & 0.160 & 0.244 & 0.131 \\
\hline C051 & 0.500 & 0.125 & 0.003 & 0.043 & 0.081 & 0.044 \\
\hline C049 & 0.450 & 0.450 & 0.009 & 0.199 & 0.293 & 0.158 \\
\hline $\mathrm{C} 047$ & 0.450 & 0.225 & 0.005 & 0.087 & 0.146 & 0.079 \\
\hline $\mathrm{C} 045$ & 0.400 & 0.500 & 0.009 & 0.226 & 0.325 & 0.175 \\
\hline $\mathrm{C} 043$ & 0.400 & 0.300 & 0.006 & 0.123 & 0.195 & 0.105 \\
\hline $\mathrm{C} 041$ & 0.400 & 0.100 & 0.003 & 0.033 & 0.065 & 0.035 \\
\hline C039 & 0.350 & 0.350 & 0.007 & 0.148 & 0.228 & 0.123 \\
\hline
\end{tabular}




\begin{tabular}{|c|c|c|c|c|c|c|}
\hline Solution Label & $\left.\mathbf{N O}_{3}{ }^{-} \mathbf{M}\right]$ & $\mathbf{N O}_{2}{ }^{-}[\mathbf{M}]$ & $\mathbf{C l}^{-}[\mathbf{M}]$ & $\mathbf{S O}_{4}{ }^{2-}[\mathbf{M}]$ & $\mathbf{H C O}_{3}{ }^{-}[\mathbf{M}]$ & $\mathbf{C O}_{3}{ }^{2-}[\mathbf{M}]$ \\
\hline $\mathrm{C} 037$ & 0.350 & 0.175 & 0.004 & 0.065 & 0.114 & 0.061 \\
\hline $\mathrm{C} 035$ & 0.300 & 0.375 & 0.007 & 0.160 & 0.244 & 0.131 \\
\hline $\mathrm{C} 033$ & 0.300 & 0.225 & 0.005 & 0.087 & 0.146 & 0.079 \\
\hline $\mathrm{C} 031$ & 0.300 & 0.075 & 0.002 & 0.024 & 0.049 & 0.026 \\
\hline $\mathrm{C} 029$ & 0.250 & 0.250 & 0.005 & 0.099 & 0.163 & 0.088 \\
\hline $\mathrm{C} 027$ & 0.250 & 0.125 & 0.003 & 0.043 & 0.081 & 0.044 \\
\hline $\mathrm{C} 025$ & 0.200 & 0.250 & 0.005 & 0.099 & 0.163 & 0.088 \\
\hline $\mathrm{C} 023$ & 0.200 & 0.150 & 0.004 & 0.054 & 0.098 & 0.053 \\
\hline $\mathrm{C} 021$ & 0.200 & 0.050 & 0.002 & 0.015 & 0.033 & 0.018 \\
\hline $\mathrm{C} 019$ & 0.150 & 0.150 & 0.004 & 0.054 & 0.098 & 0.053 \\
\hline $\mathrm{C} 017$ & 0.150 & 0.075 & 0.002 & 0.024 & 0.049 & 0.026 \\
\hline $\mathrm{C} 015$ & 0.100 & 0.125 & 0.003 & 0.043 & 0.081 & 0.044 \\
\hline $\mathrm{C} 013$ & 0.100 & 0.075 & 0.002 & 0.024 & 0.049 & 0.026 \\
\hline $\mathrm{C} 011$ & 0.100 & 0.025 & 0.001 & 0.006 & 0.016 & 0.009 \\
\hline $\mathrm{C} 009$ & 0.050 & 0.050 & 0.002 & 0.015 & 0.033 & 0.018 \\
\hline $\mathrm{C} 007$ & 0.050 & 0.025 & 0.001 & 0.006 & 0.016 & 0.009 \\
\hline $\mathrm{C} 003$ & 0.020 & 0.015 & 0.001 & 0.003 & 0.010 & 0.005 \\
\hline
\end{tabular}

\subsection{Electrochemical Testing}

Electrochemical testing was performed on ASTM A537-Cl.1 (normalized) steel, the material of construction of the Type III HLW tanks. A three electrode electrochemical testing cell consisting of a working electrode (WE), a counter electrode (CE), and a reference electrode (RE) was used for testing. The WE is the material for corrosion testing. The $\mathrm{CE}$ conducts the generated current during a controlled-potential test. The WE potential is measured relative to the RE potential, from which corrosion response can be measured. The cyclic polarization technique was used in this case to run experiments on various solution chemistries. The testing was done at a bulk solution temperature of $40{ }^{\circ} \mathrm{C}$, representative of the typical waste tank, and to reconcile with historical pitting results. The details of the steel, test technique, and test matrix are presented in this section.

\subsubsection{Steel Specifications}

The tanks were fabricated with semi-killed, hot-rolled A537-Cl.1 plate, with nominal composition shown in Table 3. The A537 steel is a ferritic/pearlitic steel with the nominal microstructure shown in Figure 6.

Table 3: Nominal Steel Specifications

\begin{tabular}{|c|c|c|c|c|}
\hline Steel Specification & $\mathrm{C}_{\max }(\mathrm{wt} \%)$ & $\mathrm{Mn}(\mathrm{wt} \%)$ & $\mathrm{P}_{\max }(\mathrm{wt} \%)$ & $\mathrm{S}_{\max }(\mathrm{wt} \%)$ \\
\hline ASTM A537 & 0.24 & $0.7-1.35$ & 0.035 & 0.035 \\
\hline
\end{tabular}



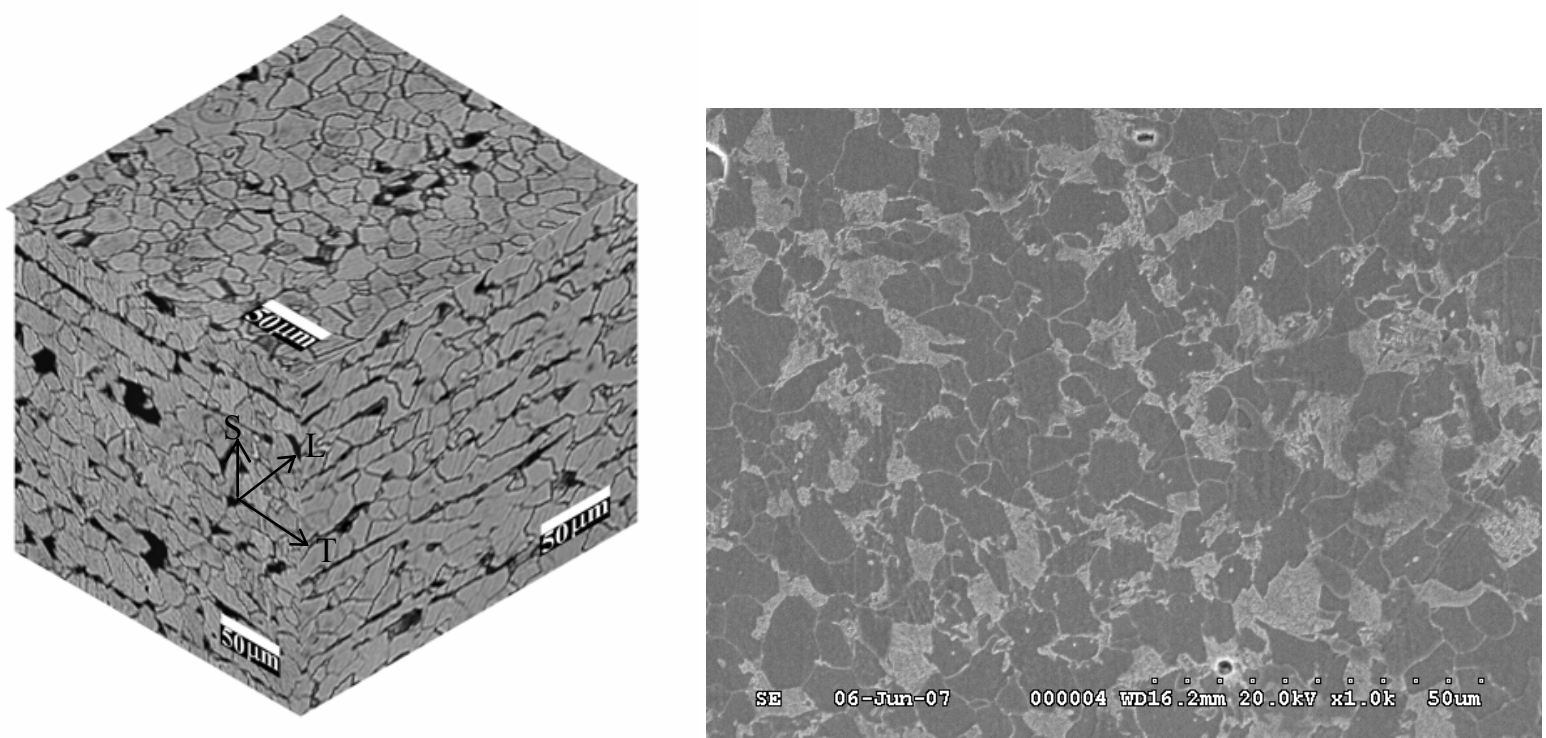

Figure 6: Microstructure/SEM Micrograph of ASTM A537 Cl.1 Steel.

\subsubsection{Cyclic Polarization Testing}

The cyclic polarization technique was used to evaluate the propensity for pitting based on a slow linear sweep of the electrochemical potential of a metal, as shown in Figure 7. The metal is first polarized towards anodic potentials then reversed towards cathodic potentials. The graphical output of the experiment is a plot of log current density versus potential. Both forward and reverse sweeps are shown on one plot. Significant hysteresis between the sweeps is an indication of pit formation. The scan is used to measure pitting and crevice corrosion susceptibility. It is also used to characterize the stability of oxide coating and to determine the effectiveness of inhibitors.

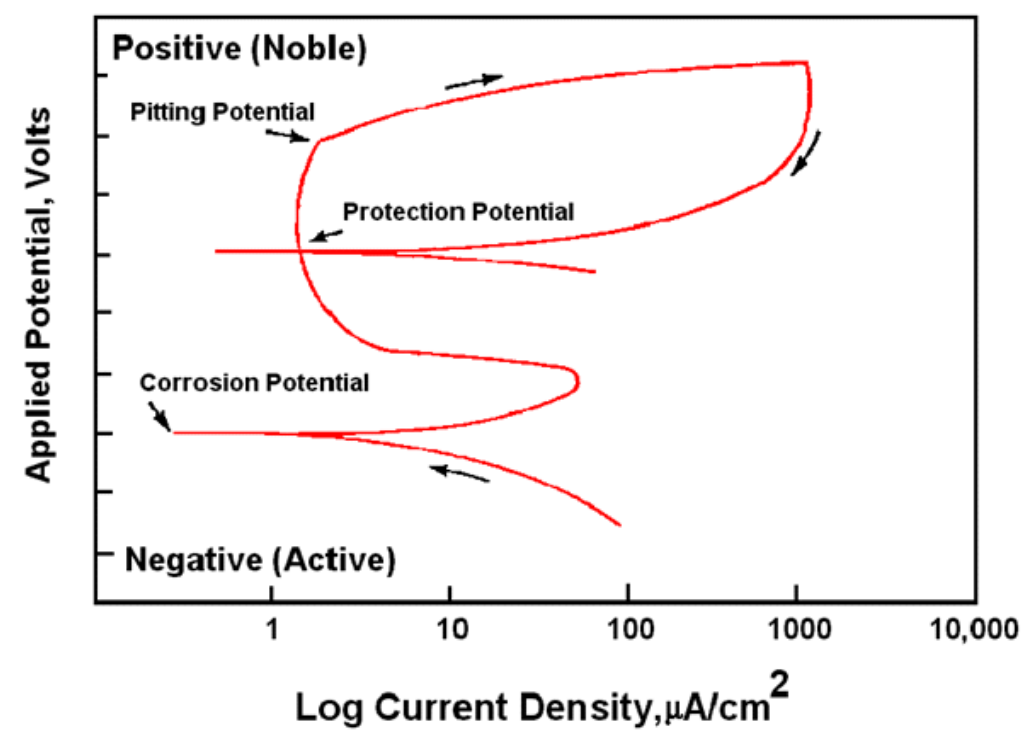

Figure 7: Schematic of Cyclic Polarization Scan

Experiments were conducted with 1.6- $\mathrm{cm}$ diameter discs as the working electrode (test specimen) with a copper wire affixed to the back of each disc using conductive epoxy adhesive. The specimen and wire were mounted in metallurgical epoxy. Test specimens were ground to 800 -grit finish prior to testing to remove native oxide layers and ensure a consistent surface finish, minimizing surface effect. The electrochemical cell was set up with two graphite rods used as the counter electrodes. The reference electrode was a $\mathrm{Ag} / \mathrm{AgCl}$ electrode for solutions $\mathrm{C} 091$ to 
C105 and saturated calumel electrode (SCE) connected to a Luggin salt bridge for solutions C001-C089. The SCE in conjunction with a Luggin bridge was used to minimize noise/interference in the scans, as well as reduce the IRdrop which can form when large distances separate the working electrode and reference electrode. [8]

Solutions were batch prepared using distilled water and reagent-grade chemicals: sodium chloride, sodium sulfate anhydrous, sodium carbonate, sodium bicarbonate, sodium nitrite, and sodium nitrate. The $\mathrm{pH}$ was maintained to 10.0 using a constant ratio of 7 to 13 for sodium carbonate to sodium bicarbonate, respectively. The gram amount of carbonate and bicarbonate added was determined based on the nitrite amount. Sodium chloride and sodium sulfate, introduced to promote corrosion, were added based on maximum amount allowable under current chemistry control limits, see L4c and L4d. Sodium nitrate and sodium nitrite varied based on statistical modeling values. Two electrochemical scans were performed simultaneously on samples submerged in solution and heated to $40{ }^{\circ} \mathrm{C}$ with heating tape and a hot plate as shown in Figure 8. The cyclic polarization scans were performed by polarizing from $-0.1 \mathrm{~V}$ vs. $\mathrm{E}_{\mathrm{OC}}$ to $1.2 \mathrm{~V}$ vs. $\mathrm{E}_{\mathrm{OC}}$ using a scan rate of $0.5 \mathrm{mV} / \mathrm{sec}$ on the forward and reverse scans.

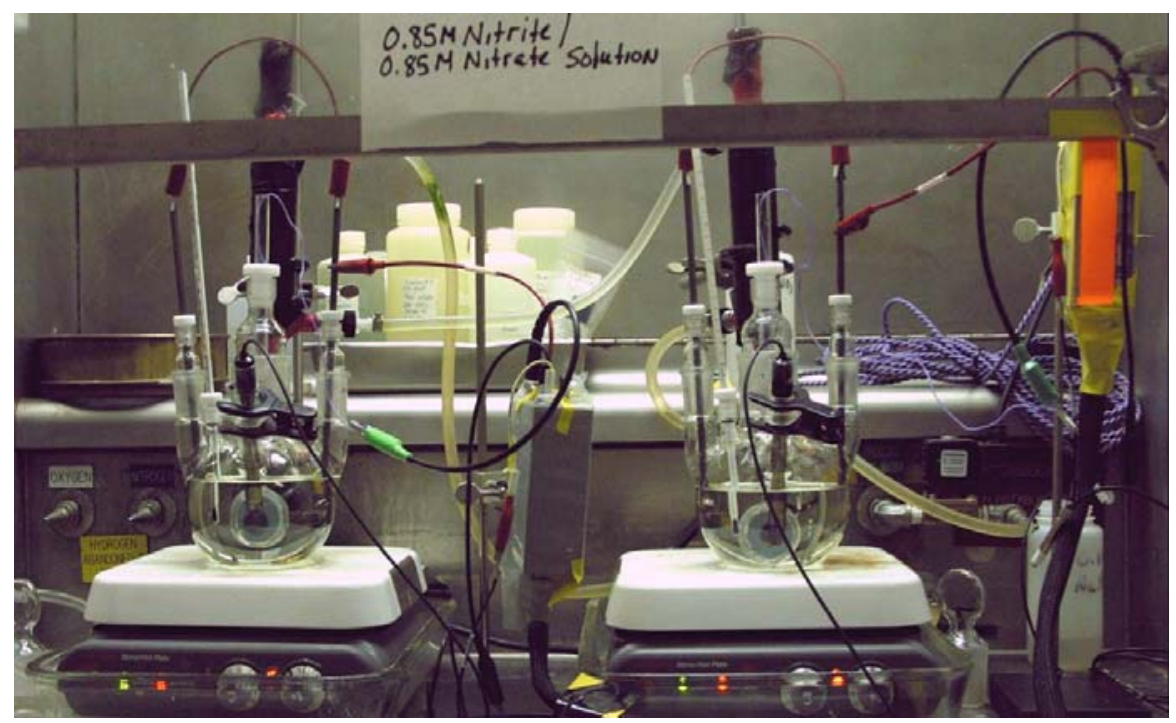

Figure 8: Electrochemical Experimental Setup

Since the cyclic potentiodynamic polarization (CPP) scan was performed over a broad range of potentials, ion chromatography was used to determine if the solution chemistry, in particular the concentration of nitrate and nitrite, was changed before and after the electrochemical scans. Results, shown in Table 4, indicate only minor variation as a result of the scans.

Table 4: Ion Chromatography Results Prior to Electrochemical Scan using C077 Solution

\begin{tabular}{|c|c|c|}
\hline COMPONENT & $\begin{array}{c}\text { Pre-Test } \\
\text { RESULTS } \\
(\boldsymbol{\mu g} / \mathbf{m l})\end{array}$ & $\begin{array}{c}\text { Post-Test } \\
\text { RESULTS } \\
(\boldsymbol{\mu g} / \mathbf{m l})\end{array}$ \\
\hline FLUORIDE & 20 & 20 \\
\hline FORMATE & 100 & 100 \\
\hline CHLORIDE & 202 & 238 \\
\hline NITRITE & 15700 & 18800 \\
\hline NITRATE & 43300 & 48900 \\
\hline PHOSPHATE & 100 & 100 \\
\hline SULFATE & 11800 & 13700 \\
\hline OXALATE & 100 & 100 \\
\hline BROMIDE & 100 & 100 \\
\hline
\end{tabular}


Visual observations were made on the coupons at the conclusion of the CPP scans to determine extent of corrosion on the surface. These observations were used to categorize the relative corrosivity of the solutions towards the steel. The observations were then correlated with the CPP scans.

\section{RESULTS AND DISCUSSION}

Several critical data from the CPP scans were recorded when available and used to determine the propensity for pitting. These were the corrosion potential or open-circuit potential (OCP), the pitting potential, and the repassivation potential. The open circuit potential is the equilibrium potential coordinant with no net current transfer. The pitting potential is typically associated with a large increase in current at an essentially constant potential indicating the localized breakdown in passivity, and consequent pitting. This pitting potential can manifest as a breakdown potential near the OCP, or can be limited to the transpassive regime of the scan. The presence of a breakdown potential near the OCP indicates high susceptibility to pitting, while breakdown only at the transpassive regime indicates strong resistance to pitting. The repassivation potential is where the current density re-crosses the passive portion on the reverse leg of the cyclic polarization scan, indicating passivation and consequent cessation of pitting. However, a CPP scan without a repassivation potential indicates that the pitting is self-propagating and the passive film never returns to its protective state. The lack of a repassivation potential may also be indicative of crevice corrosion, which can be determined by visual examination of the electrochemical test coupon. This subset of CPP scan data were used to determine any single-variable effects on the potential data; however, once the test matrix is complete, multi-variate statistical methods will be used to determine any synergistic effects.

The surfaces of the electrochemical coupons were also examined microscopically for the presence of corrosion after the CPP scans were completed. Corrosion of the electrochemical test coupons can be used to confirm the propensity for pitting as well as determine the potentials at which localized corrosion is possible. Time-lapse photography was used on selected tests to confirm that pitting occurred only in the transpassive regime of the CPP scans. The results of the CPP scans and the surface examinations are discussed in the subsections below.

\subsection{CPP Scans}

The open-circuit data were analyzed to determine any effect of the solution constituents on the OCP. The OCP data, shown in Figure 9, did not suggest any obvious and consistent variation of OCP as a function of nitrate concentration in the ranges tested, consistent with literature data on cyclic polarization scans performed on inhibited solutions.[9] 


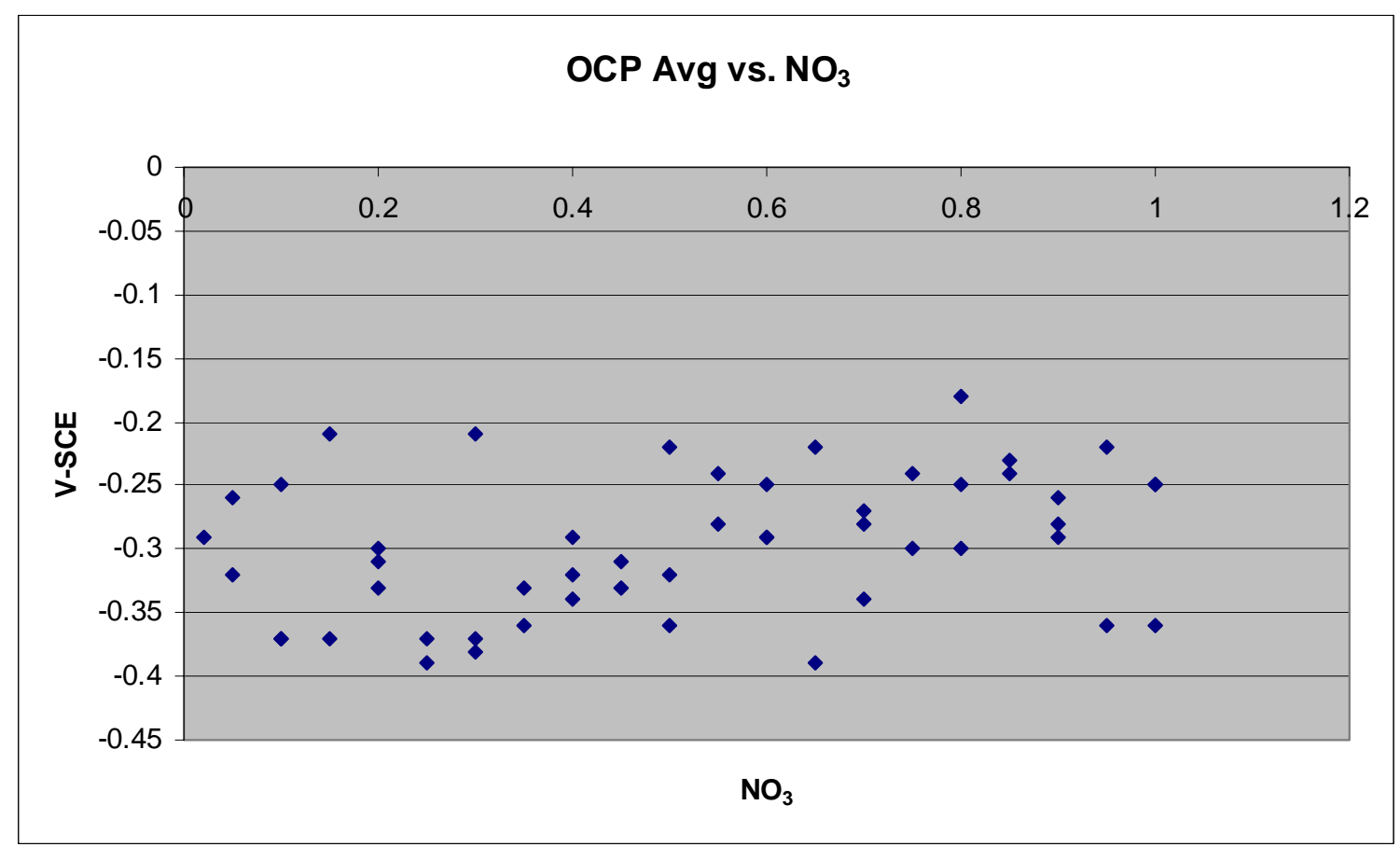

Figure 9: Open-Circuit Potential as a Function of Nitrate Concentration

Trends in the OCP as a function of R-value were also investigated as shown in Figure 10. The R-value is defined to be the ratio of the molar concentrations of inhibitor species (nitrite) to the sum of the aggressive species (nitrate, chloride and sulfate), The R-value is a simple comparison between chemistries and can be utilized to assess the potential for corrosion.[10] High R-values indicate that the potential for corrosion is minimal, while low R-values indicate a high potential for corrosion due to insufficient inhibitor concentrations. The OCP data did not indicate any trends with simple statistical analysis. 


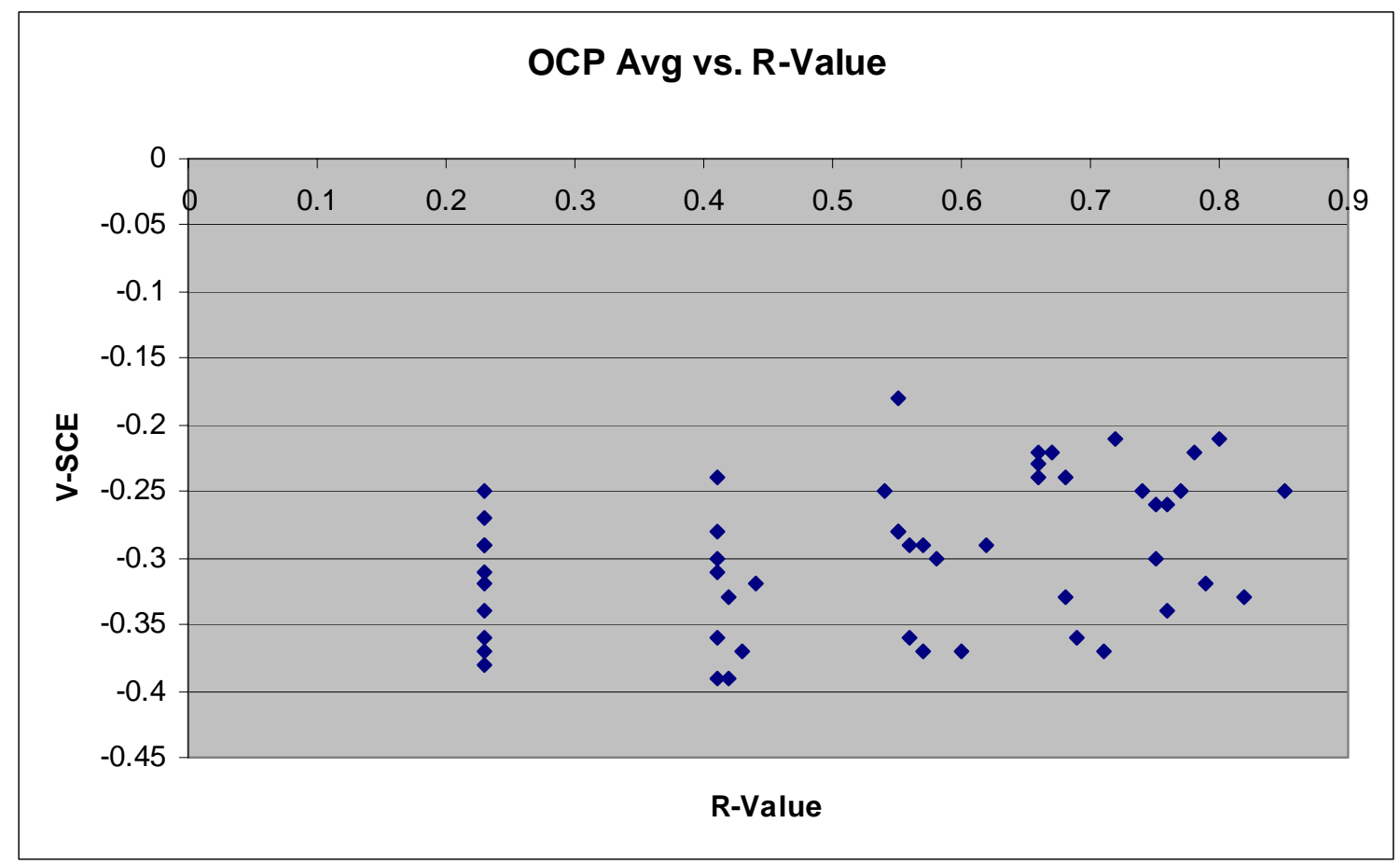

Figure 10: Open Circuit Potential as a Function of R-Value

The data were also analyzed to determine the presence of a pitting potential related to the breakdown of passivity prior to polarization into the transpassive regime. The broad majority of the CPP scans during the testing indicated breakdown only at the transpassive region at a potential of approximately $800 \mathrm{mV}$-SCE, particularly at high Rvalues, as shown in Figure 11. However, there were several data that indicated a breakdown potential prior to polarization into the transpassive region, as shown in Figure 11. In addition, it is seen that the breakdown potentials at lower R-values have a broad variation, but primarily occurred at lower than the transpassive region. As the Rvalues increase, the breakdown potentials tend to increase towards the transpassive, and indicate less variation with the exception of a few data points. 


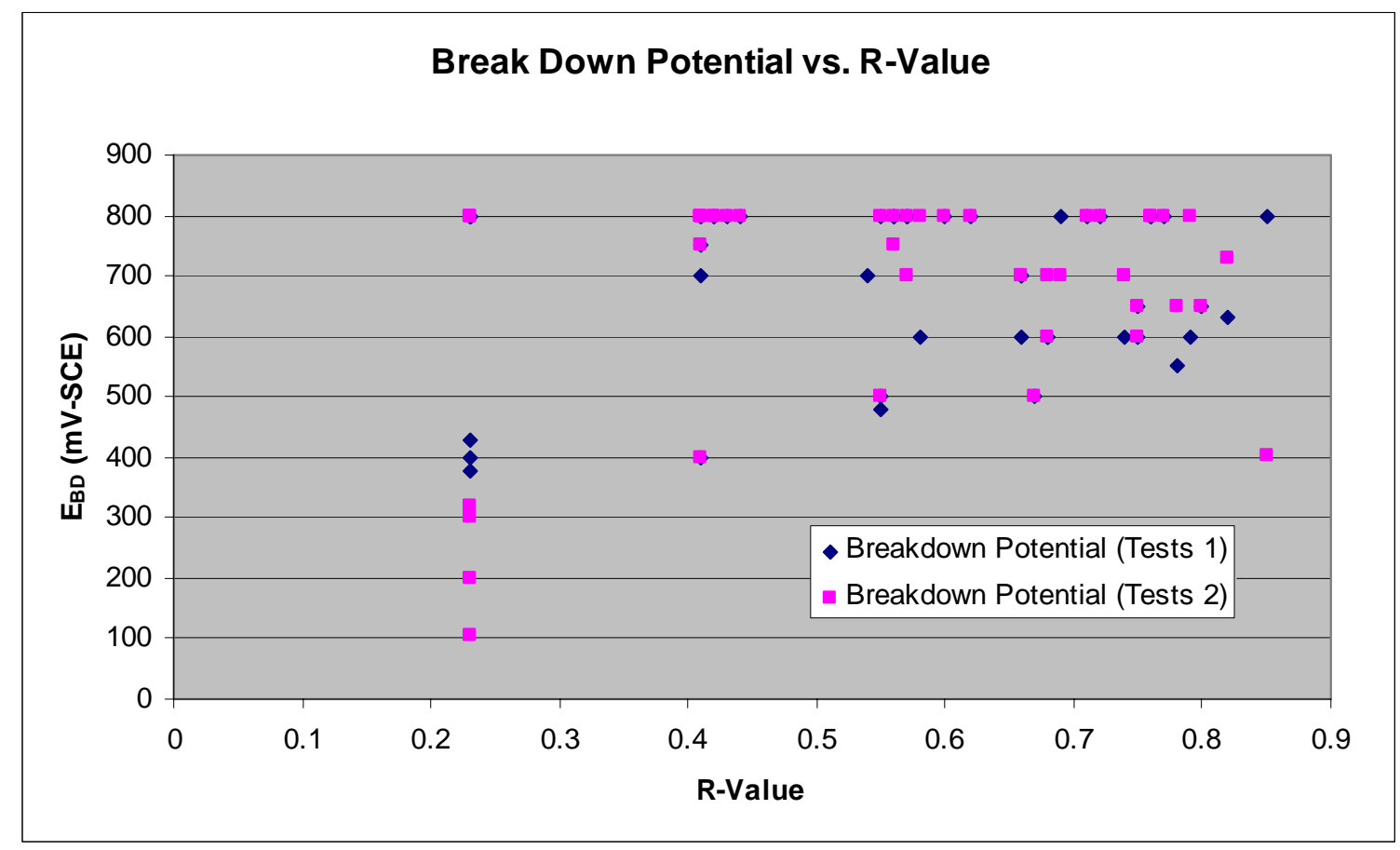

Figure 11: Breakdown Potential as a Function of R-Value

Literature data have indicated breakdown potentials near - $250 \mathrm{mV}$-SCE on CPP scans with nitrate concentrations greater than $0.1 \mathrm{M}$ when the solution $\mathrm{pH}$ is 9.73 and does not contain nitrites. These breakdown potentials indicated a significant increase in current density beyond the limiting current density of the testing and were obviously lacking repassivation, suggesting pitting that was self-propagating. In addition, the pitting potential decreased near the OCP with chloride concentrations greater than $0.1 \mathrm{M}$ even with $0.11 \mathrm{M}$ nitrite present but with a solution $\mathrm{pH}$ of 9.73.[11] The literature experiments concluded that chloride was a more aggressive pitting agent relative to nitrate and found that the pitting potential varied as the simple function:

$$
\begin{aligned}
& \mathbf{E}_{\mathbf{p}}=\mathbf{A}-\mathbf{B} \log \mathbf{C}_{\mathbf{i}} \\
& \text { Where: } \begin{aligned}
\mathrm{E}_{\mathrm{p}} & =\text { pitting potential }(\mathrm{mV}) \\
\mathrm{A}, \mathrm{B} & =\text { Constants (depending upon materials/environment } \\
\mathrm{C}_{\mathrm{i}} & =\text { halide concentration (M) (in this case, chloride) }
\end{aligned}
\end{aligned}
$$

In contrast to literature data, however, these tests indicate that the breakdown is limited in terms of current density increase allowing for further polarization through the occurrence of a passive region. The current density did not increase beyond the limit set by the experimental parameters. The data showing a premature breakdown were similar to the curve shown in Figure 12. The initial breakdown potential was followed by a region indicative of a passive current density. The transpassive region was reached upon further polarization; however, on the reverse scan there was a crossover through the initial breakdown plateau. Ultimately, there was no traditional repassivation potential. However, the high delta between the OCP and the transpassive potential in these tests may indicate sufficient inhibition due to the slightly higher $\mathrm{pH}$ relative to literature data and confirms the inhibitory nature of the chemistry controls for chloride and sulfate. 


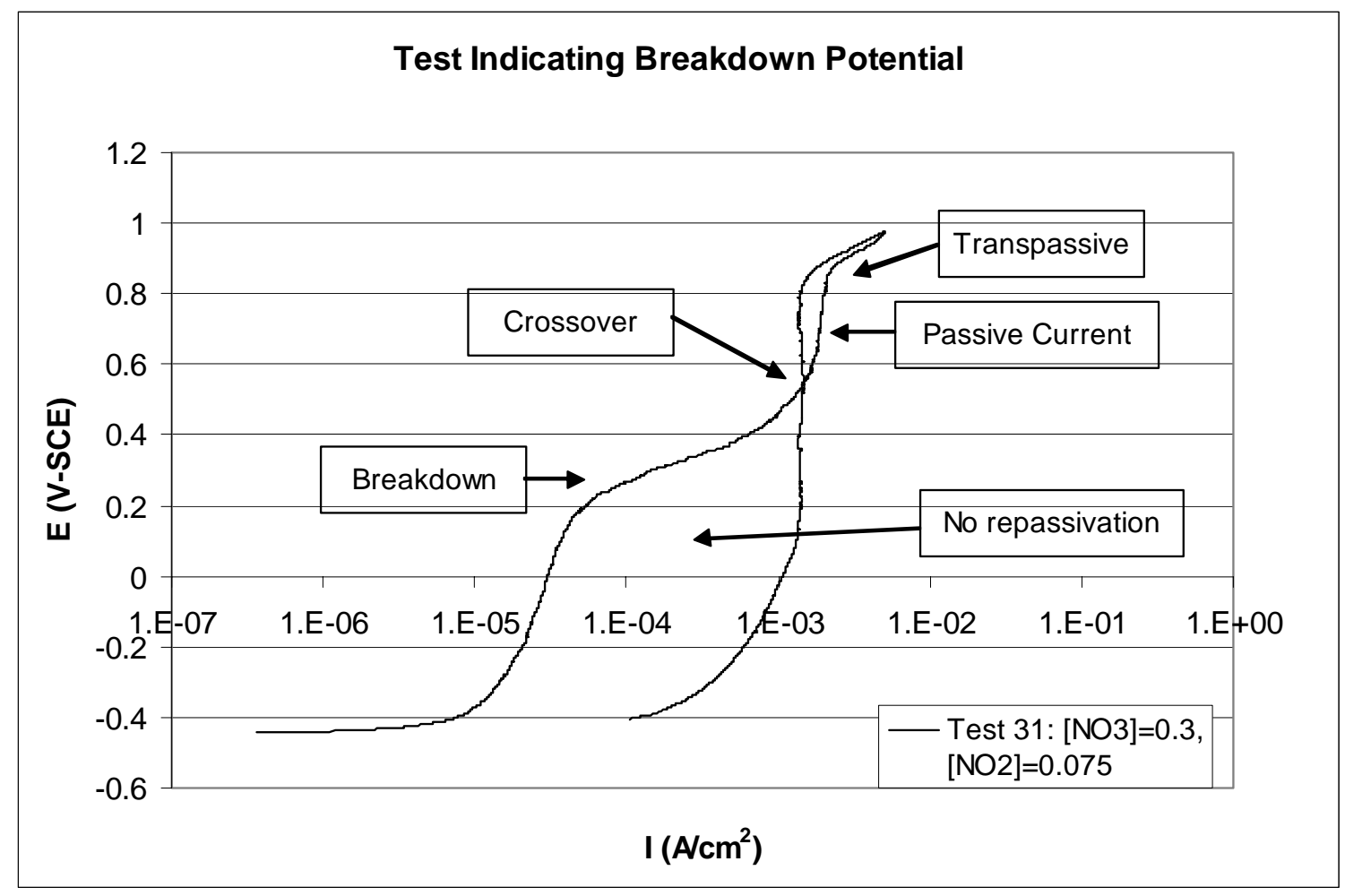

Figure 12: Test Indicating Premature Breakdown

The passive current densities during the CPP scans were also analyzed to determine any significant changes in the protective capacity of the passive film. An increase in the passive current density is typically indicative of reduction in the protectiveness of the passive film. The passive current densities in these tests, shown in Figure 13, varied approximately between $1-100 \mu \mathrm{A} / \mathrm{cm}^{2}$, with the exception of one outlier. However, the trends indicate that the passive current density is decreasing as the R-value increases.[9] While previous testing has shown an increase in the passive current density with increasing nitrate concentration, the testing here is better represented as a function of R-value since high nitrate concentrations typically included higher inhibitor levels.

The variance of the passive current density is sufficiently significant to derive effects in the CPP response; however, single variable analysis is insufficient to determine synergistic effects of the chemistries. Once the testing is complete, multi-variate statistics will be used to elucidate any synergistic effects on the passive current densities. However, in general, it appears that the passive current density is falling with increasing nitrate concentrations, which in these tests, are concurrent with increasing inhibitor concentration. Therefore, the results appear consistent with highly inhibited solutions. 


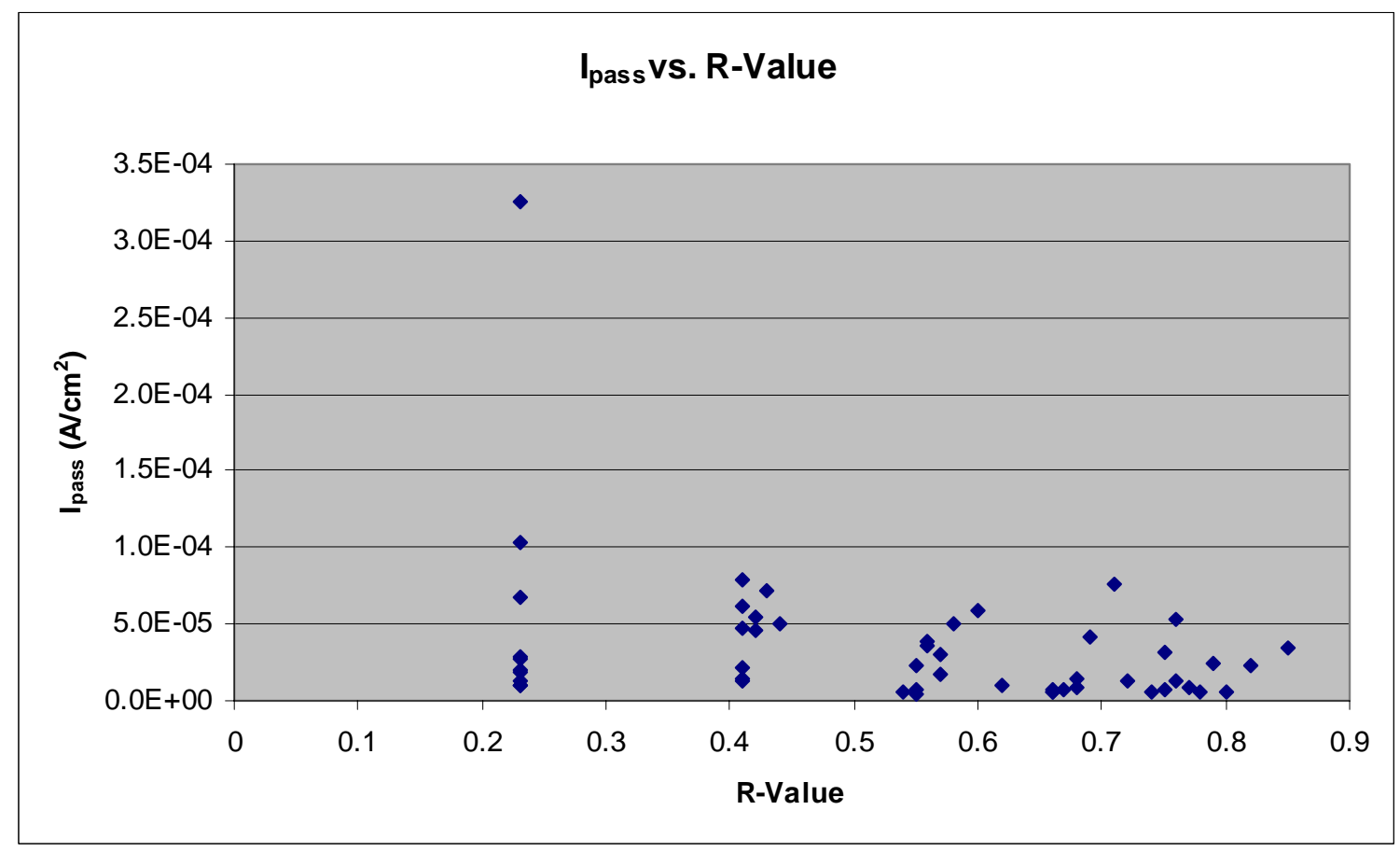

Figure 13: Passive Current Density as a Function of R-Value

\subsection{Visual Observations}

The working electrode was also visually examined at the completion of the CPP scans. Optical microscopy was used to qualitatively assess the amount of visible corrosion on the working electrode surface and compared with the electrochemical test results. The results of the visual examination are shown in Figure 15 as a function of nitrite/nitrate concentrations with the current corrosion control limit overlaid. The extent of corrosion was categorized as (1) none, (2) moderate, or (3) significant. The tests resulting in a working electrode surface as pristine after polarization as prior to the scan were categorized as "none". Working electrode surfaces that were pockmarked with corrosion, regardless of depth, were categorized as "moderate". Working electrode surfaces that exhibited corrosion product growth or showed corrosion over the broad majority of the surface area were categorized as "significant". Examples of each of these categories are shown in Figure 14.

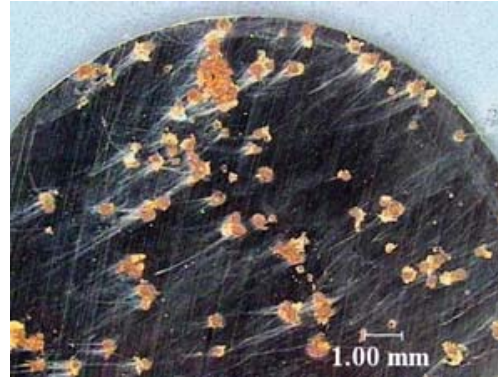

Heavy Pitting, Test 81

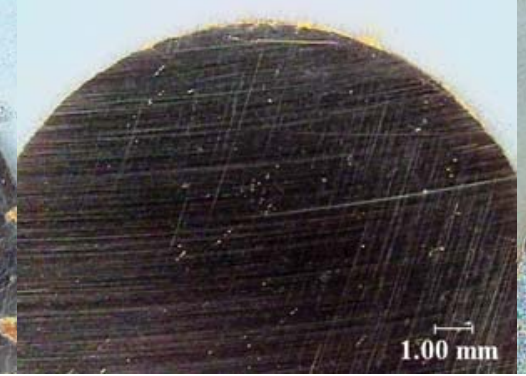

Moderate Pitting, Test 83

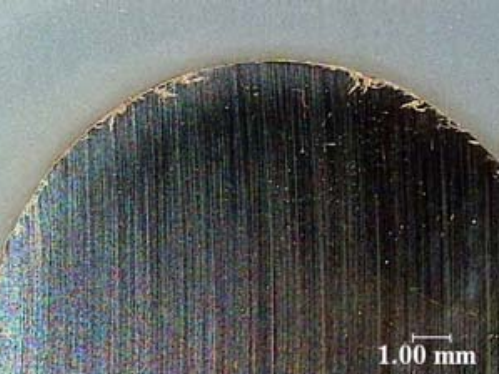

No Pitting, Test 85

Figure 14: Categorization of Visual Observations

These results are summarized in Figure 15 as a function of nitrite and nitrate. The summary indicates that the lowest level of inhibitors have several data points that resulted in heavy corrosion, while the majority of the data points near 
the current chemistry control limit did not corrode. However, the most dilute solutions were subject to corrosion throughout the ranges tested.

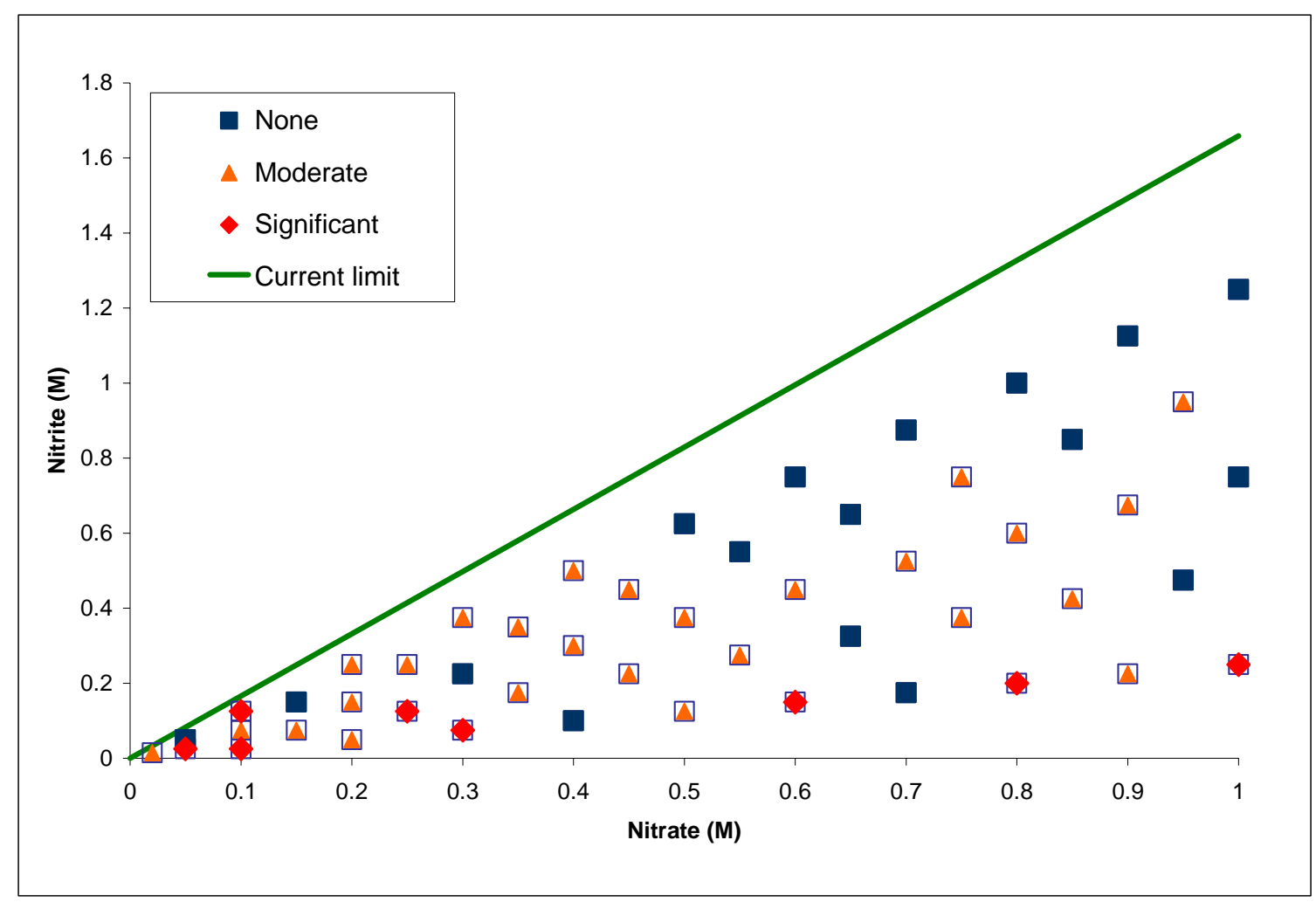

Figure 15: Visual Observations on Working Electrode Surface

It is important to correlate the visual observations on the working electrode surface with the cyclic polarization scans. The working electrode surfaces were monitored with video during the CPP scans to determine when pitting may have initiated and/or propagated. Visual inspections may have indicated heavy pitting, which may have occurred only in the transpassive region, well beyond the OCP. However, pitting initiation at electrochemical potentials nearer the OCP with the presence of a breakdown potential would have been observed during time lapse photography.

Sample 23 was continuously monitored during the electrochemical run using solution C061, which contained 0.60 $\mathrm{M}$ nitrate and $0.15 \mathrm{M}$ nitrite. The time-lapse photographs are overlaid on the CPP scan shown in Figure 16. This CPP scan exhibited a small "breakdown potential" near the 400mV-SCE mark similar to the curve shown in Figure 12. However, this breakdown of the film is much less pronounced and resulted in small increase in current density followed by another short range of passivity. However, a hysteresis is evident on the reverse scan, and although the current density of the reverse scan is nearly that of the forward scan, the repassivation potential is very near the OCP, indicating large regions of potential pitting. The photographs confirm that pitting does not occur until the small breakdown (or change in) of the passive film; however, the pitting continues to grow throughout the CPP scans. The pitting appears to be broad and shallow and the breakdown occurs at nearly 1V-SCE polarization, indicating this condition is largely inhibited against pitting. 


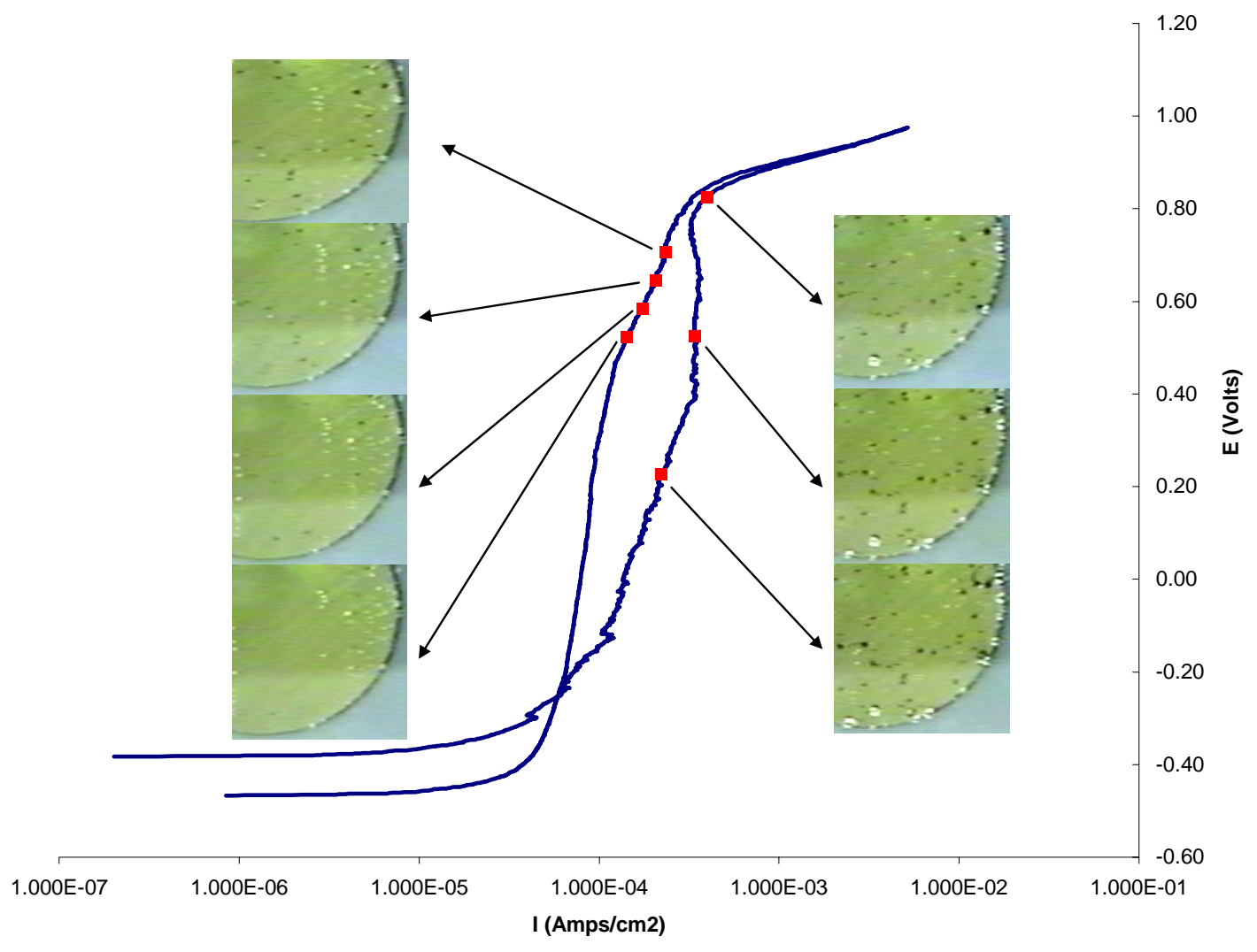

Figure 16: Corrosion Changes during Electrochemical Run using C061

\subsection{Analysis of Critical Data Points}

Two regions are of critical interest to potential reductions in the chemistry control program: (1) the lowest level of inhibitor additions, and (2) the highest concentration of nitrate salts. These two regions are demarcated in Figure 17. Developing an understanding of the corrosion response with the lowest inhibitor additions can reveal the minimum necessary parameters to prevent pitting. The corrosion response at $1 \mathrm{M} \mathrm{NaNO}_{3}$ concentrations provides the greatest potential savings in inhibitor additions. 


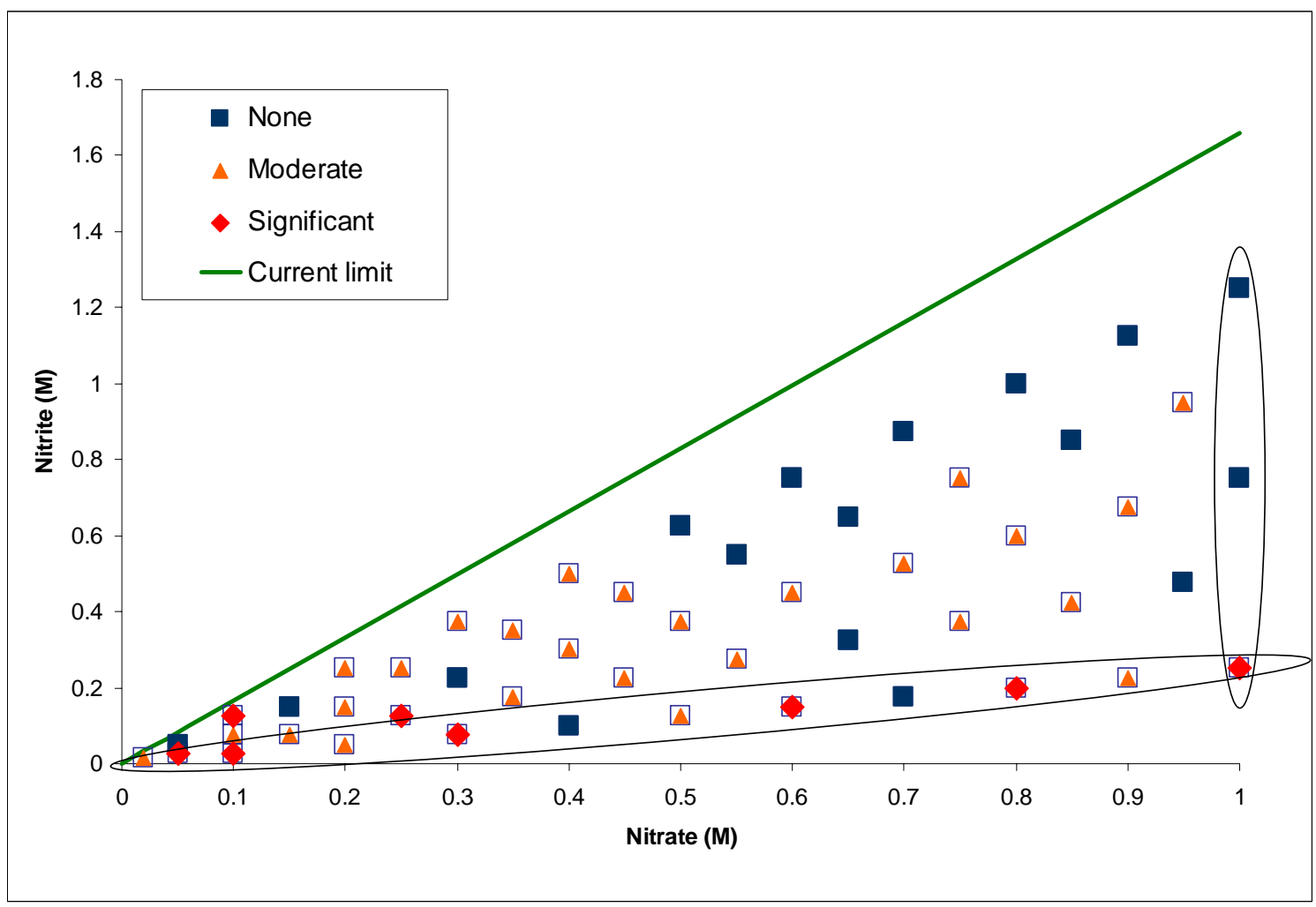

Figure 17: Critical Locations of Greatest Potential Chemistry Control Reductions

The test data that revealed significant corrosion occurred on coupons when tested in conditions with the lowest amount of nitrite added are shown in Table 5. The data had a consistent ratios and R-values with the exception of the most dilute solution.

Table 5: Test Data which Indicated Significant Corrosion upon Visual Observation

\begin{tabular}{|c|c|c|c|c|c|c|}
\hline Test & $\mathbf{N O}_{3}$ & $\mathbf{N O}_{2}$ & $\mathbf{C l}$ & $\mathbf{S O}_{4}$ & $\mathbf{N O}_{2} / \mathbf{N O}_{3}$ & R-Value \\
\hline C007 & 0.05 & 0.025 & 0.000986 & 0.006377 & 0.5 & 0.44 \\
\hline C011 & 0.1 & 0.025 & 0.000986 & 0.006377 & 0.25 & 0.23 \\
\hline C031 & 0.3 & 0.075 & 0.002239 & 0.023584 & 0.25 & 0.23 \\
\hline C061 & 0.6 & 0.15 & 0.003755 & 0.053826 & 0.25 & 0.23 \\
\hline C081 & 0.8 & 0.2 & 0.004655 & 0.07581 & 0.25 & 0.23 \\
\hline C101 & 1 & 0.25 & 0.005498 & 0.098877 & 0.25 & 0.23 \\
\hline
\end{tabular}

The CPP scans for these data, shown in Figure 18, suggest several important trends. The CPP scan performed in the most dilute solution, Test 7: R-value of 0.44 , did not contain any evidence of a breakdown potential, suggesting that the observable corrosion initiated in the transpassive region, but had a repassivation potential near the OCP with a significant hysteresis which allowed corrosion propagation. The remaining tests were performed at a constant $\mathrm{NO}_{2} / \mathrm{NO}_{3}$ ratio and R-value. Tests 11 and 31, with increasing salt concentrations, resulted in an increase in the current densities as well as pronounced breakdown potentials and "crossovers", schematically shown in Figure 12. However, tests 61, 81, and 101 resulted in lower current densities and less pronounced breakdowns with increasing anionic concentrations. This phenomenon suggests that either the absolute value of nitrate or nitrite concentration is critical in preventing pitting and corrosion, rather than the ratio of inhibitor to aggressive anions. This is critical in that if the absolute value of nitrite is the controlling parameter, then a plateau potentially exists beyond which nitrite addition as a corrosion inhibitor does not add value. 


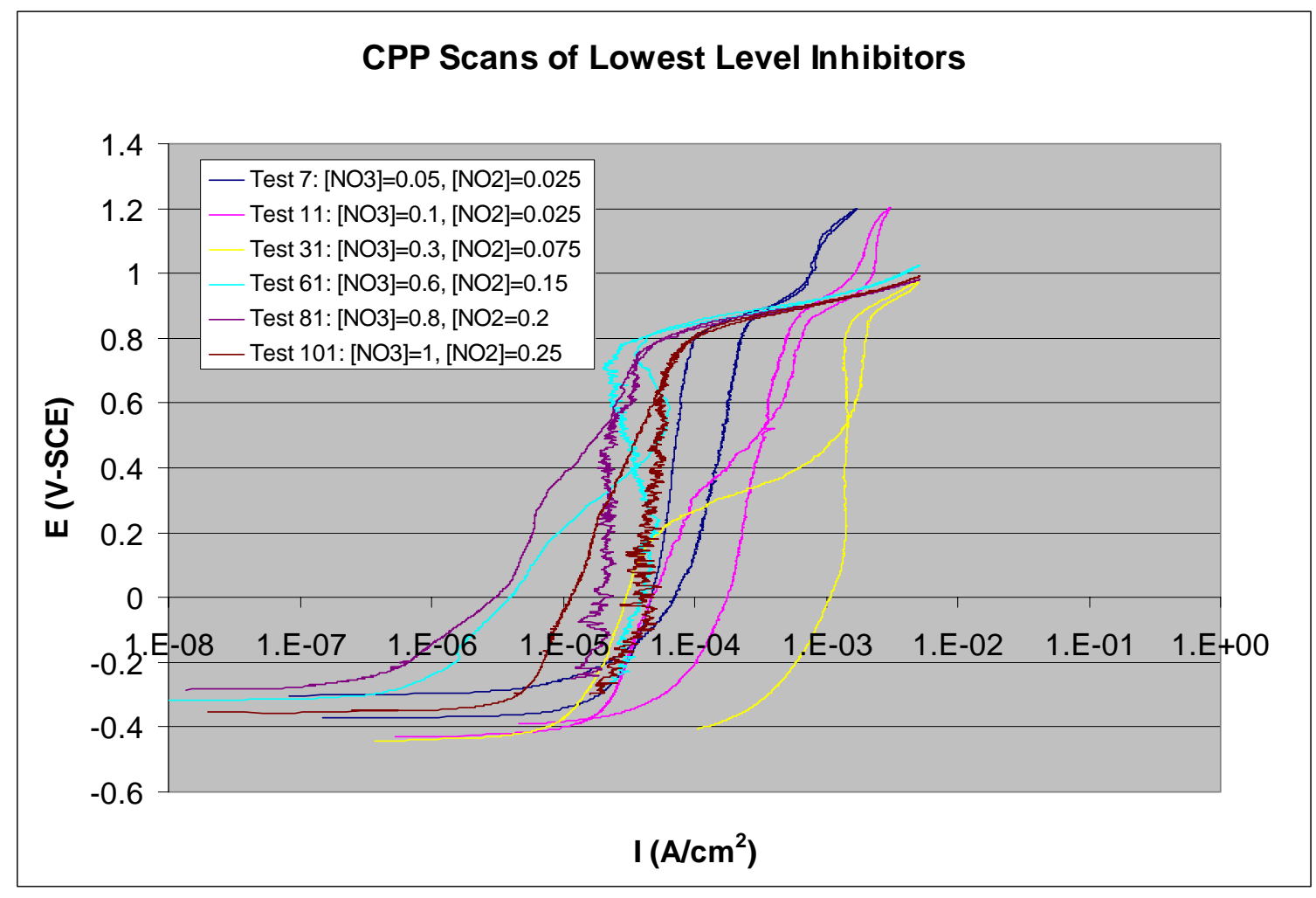

Figure 18: CPP Scans with Lowest Level of Nitrite Inhibitor Addition

The hypothesis of an absolute value of critical nitrite concentration beyond which pitting is controlled was tested against the data taken on CPP scans performed with $1 \mathrm{M} \mathrm{NaNO}_{3}$, as shown in Figure 19. The scans indicate a lower passive current density with increasing nitrite concentration and crossover on the reverse scan very near the OCP. This indicates that the solution is largely inhibited. The CPP scans performed in tests $103\left(\mathrm{NO}_{2}=0.75 \mathrm{M}\right)$ and 105 $\left(\mathrm{NO}_{2}=1.25 \mathrm{M}\right)$ did not change suggesting that $0.75 \mathrm{M}$ nitrite is sufficient to inhibit against pitting in this regime and any additional nitrite does not increase inhibition, i.e. a plateau effect. The visual observations on the coupon confirm that test 101 resulted in significant corrosion, while tests 103 and 105 did not sustain any corrosion attack even when polarized into the transpassive region. Literature data on the efficacy of the nitrite inhibitor against chloride, sulfate, and nitrate attack on mild steel claims a linear relationship on the log-log inhibitor/aggressor scale.[12] However the data presented in the literature may be credited with the absolute value of nitrite being the critical factor since the aggressive anions were maintained constant through the testing. 


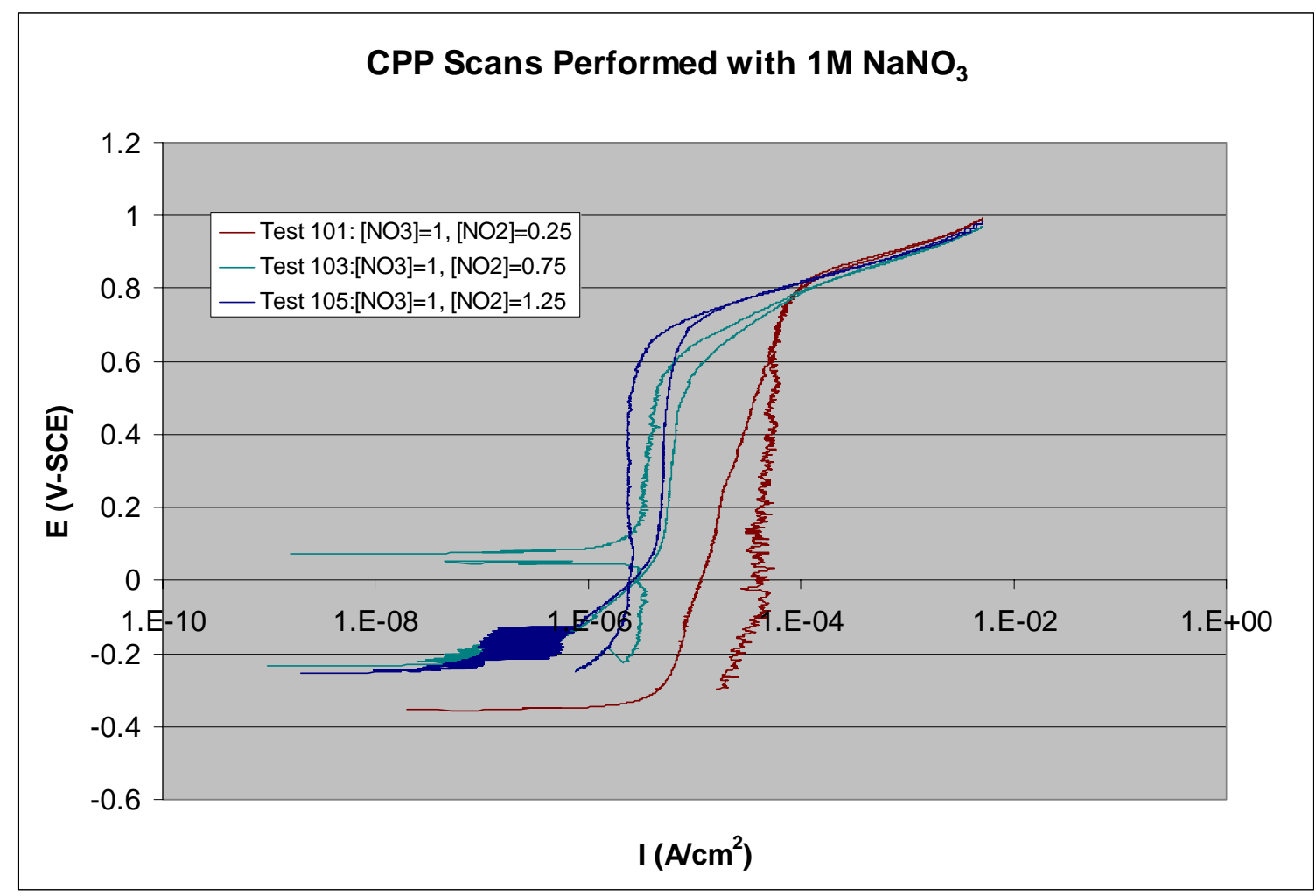

Figure 19: CPP Scans Performed with 1M NaNO

\section{INTERIM CONCLUSIONS}

The technical approach to develop a probability-based chemistry control program was based upon gathering sufficient data to develop a predictive tool for corrosion vulnerability. Electrochemical testing, i.e. cyclic polarization testing, is being performed within the framework of a statistical test matrix to determine electrochemical regimes in which low carbon steel is susceptible to pitting based on a slow linear sweep of the electrochemical potential. The statistical test matrix consists of 105 data points which include various concentrations of the aggressive nitrate/chloride/sulfate anions and the nitrite inhibitor. Each of the data points lies below the current chemistry control program so that a quantified probability of pitting may be used to realize savings in inhibitor additions to tanks that are potentially out of the current specifications.

A subset of the original statistical test matrix, comprising of 50 electrochemical tests was used to develop a fundamental understanding of the corrosion response of the materials in the various environments. The interim results suggest that there lies some critical nitrite concentration that sufficiently inhibits against localized corrosion mechanisms due to nitrates/chlorides/sulfates, beyond which any nitrite additions are unnecessary. The combination of visual observation and the CPP scans indicate a potential for significant inhibitor reductions without consequence specifically at nitrate concentrations near $1 \mathrm{M}$.

The electrochemical testing for the remainder of the statistical matrix is being completed. The complete data sets will be used to determine the statistical basis to confidently inhibit against pitting using nitrite inhibition with the current $\mathrm{pH}$ controls. Complementary coupon testing is also being performed to confirm the electrochemical test scans and to determine any interfacial or vapor space corrosion effects. Once complete, a revised chemistry control program will be devised based upon the probability of pitting specifically for dilute solutions which will allow for tank specific chemistry control implementation. 


\section{$\underline{\text { References }}$}

[1] B.J. Wiersma and R.L. Sindelar, "SRS High Level Waste Tank and Piping Systems - Structural Integrity Program and Topical Report," WSRC-TR-95-0076, June 1995.

[2] P.E. Zapp and D. T. Hobbs, "Inhibiting Pitting Corrosion in Carbon Steel Exposed to Dilute Radioactive Waste Slurries," Paper no. 98, CORROSION-92, NACE, Houston, TX, 1992.

[3] P.E. Zapp, "Effect of Nitrite Concentration on Pit Depth in Carbon Steel Exposed to Simulated Waste," Paper no. 172, CORROSION-98, NACE International, Houston, TX, 1998.

[4] P.E. Zapp, "Recommended Nitrite Limits for Chloride and Sulfate in ESP Slurries," Westinghouse Savannah River Company, WSRC-TR-94-0250, 1994.

[5] T.B. Edwards, to: J.I. Mickalonis, et al., "A Second Statistically Designed Experiment to Support the Study of Corrosion Inhibition,” SRNL-SCS-2005-00024, May 2005.

[6] J.W. Congdon, "Inhibition of Nuclear Waste Solutions Containing Multiple Aggressive Anions," Materials Performance 2234 (1988).

[7] D. T. Hobbs and R. M. Wallace, "Hydroxide Depletion in Waste Storage Tanks by Reaction with Carbon Dioxide,” DPST-85-846, October 14, 1985.

[8] W.S. Tait., An Introduction to Electrochemical Corrosion Testing for Practicing Engineers and Scientists. 1994, Racine, WI: Pair O Docs Publications.

[9] P.E. Zapp and J. W. Van Zee, "Electrochemical Studies of Nitrate-Induced Pitting in Carbon Steel," Paper No. 471, CORROSION-99, NACE-International, Houston TX, 1999.

[10] B.J. Wiersma to: J.E. Marra, "Clarification of Temperature Limits for Waste Solutions with Nitrate Concentrations Greater than 1 Molar," WSRC-TR-94-0333, Westinghouse Savannah River Company, August 8, 1994.

[11] P.E. Zapp and J.W. Van Zee, "Mechanism of Corrosion Prevention by Nitrite in Carbon Steel Exposed to Dilute Salt," WSRC-TR-2002-00078, Westinghouse Savannah River Company, July 2002.

[12] A.D. Mercer, I.R. Jenkins, and J.E. Rhoades-Brown, "Comparative Study of Factors Influencing the Action of Corrosion Inhibitors for Mild Steel in Neutral Solutions,” British Corrosion Journal, 3:3 (1968) 136. 